Prepared in cooperation with the U.S. Fish and Wildlife Service

\title{
Changes in Aquatic Prey Resources in Response to Estuary Restoration in Willapa Bay, Southwestern Washington
}

Open-File Report 2018-1194 
Cover: Photograph showing Ellsworth Creek site, Willapa National Wildlife Refuge, Washington. Photograph by Sierra Blakely, U.S. Geological Survey, June 8, 2015. 


\section{Changes in Aquatic Prey Resources in Response to Estuary Restoration in Willapa Bay, Southwestern Washington}

By Isa Woo, Melanie J. Davis, and Susan De La Cruz

Prepared in cooperation with the U.S. Fish and Wildlife Service

Open-File Report 2018-1194

U.S. Department of the Interior

U.S. Geological Survey 


\section{U.S. Department of the Interior \\ RYAN K. ZINKE, Secretary}

\section{U.S. Geological Survey James F. Reilly II, Director}

U.S. Geological Survey, Reston, Virginia: 2018

For more information on the USGS-the Federal source for science about the Earth, its natural and living resources, natural hazards, and the environment-visit http://www.usgs.gov/ or call 1-888-ASK-USGS (1-888-275-8747).

For an overview of USGS information products, including maps, imagery, and publications, visit https:/store.usgs.gov.

The findings and conclusions in this report are those of the authors and do not necessarily represent the views of the U.S. Fish and Wildlife Service.

Any use of trade, firm, or product names is for descriptive purposes only and does not imply endorsement by the U.S. Government.

Although this information product, for the most part, is in the public domain, it also may contain copyrighted materials as noted in the text. Permission to reproduce copyrighted items must be secured from the copyright owner.

Suggested citation:

Woo, I., Davis, M.J., and De La Cruz, S., 2018. Changes in aquatic prey resources in response to estuary restoration in Willapa Bay, southwestern Washington: U.S. Geological Survey Open-File Report 2018-1194, 32 p., https://doi.org/10.3133/ofr20181194. 


\section{Contents}

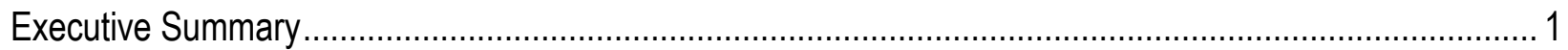

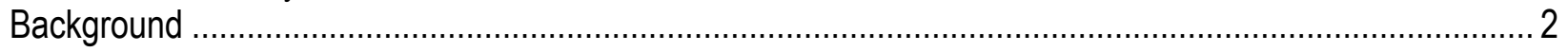

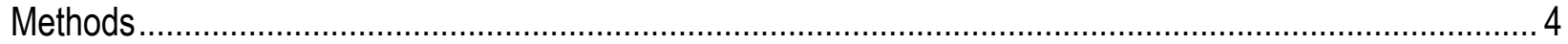

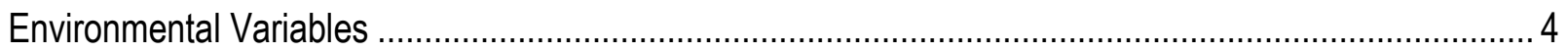

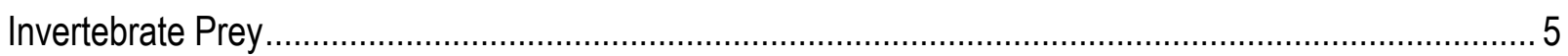

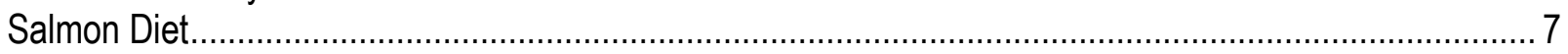

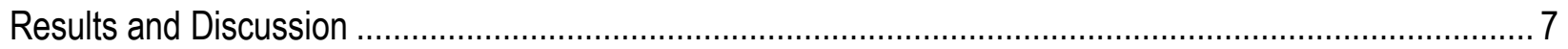

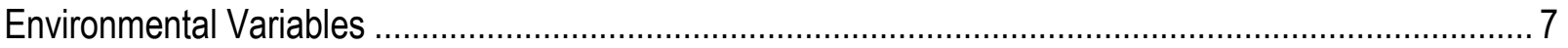

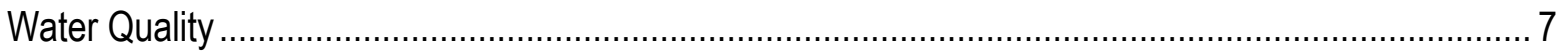

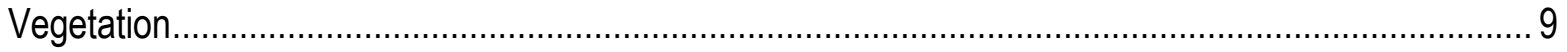

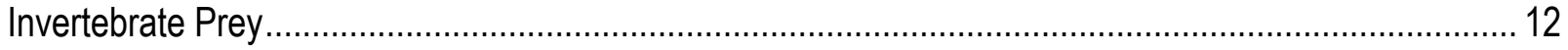

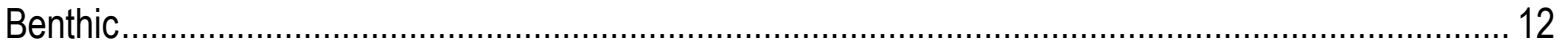

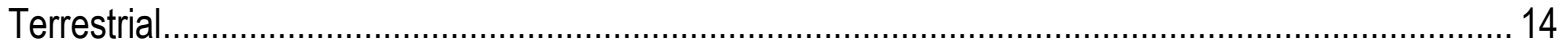

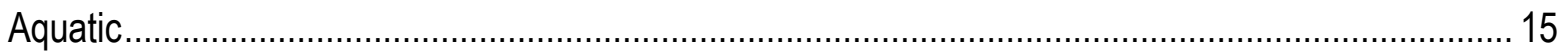

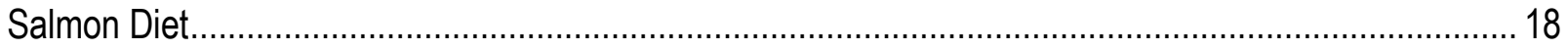

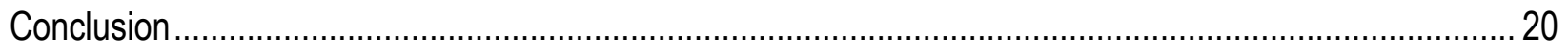

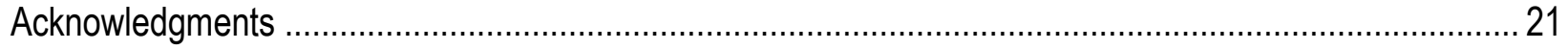

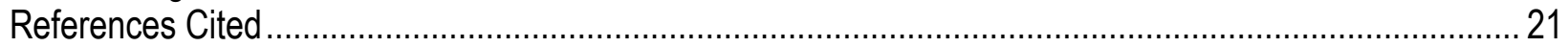

Appendix 1. Total Abundance of (Epi) Benthic Invertebrate Prey Taxa Collected from Samples in

Willapa Bay, Washington, 2014-15 .................................................................................... 24

Appendix 2. Total Abundance of Terrestrial Invertebrate Prey Taxa Captured in Fallout Traps from

Willapa Bay, Washington, 2014-15 ...................................................................................... 26

Appendix 3. Total Abundance of Aquatic Invertebrate Prey Taxa Collected from Willapa Bay,

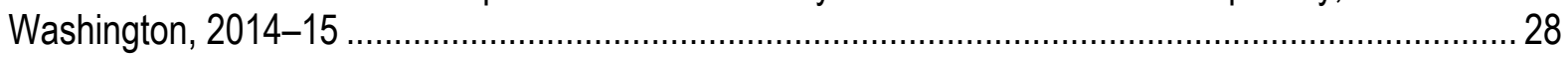

Appendix 4. Total Abundance of Terrestrial Drift Invertebrate Prey Taxa Collected from Willapa Bay,

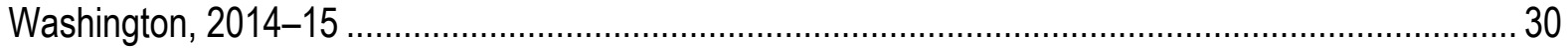

Appendix 5. Field Photographs................................................................................................. 31 


\section{Figures}

Figure 1. Map of study sites for invertebrates (led by the U.S. Geological Survey Western Ecological Research Center) and salmon (led by the Columbia River Estuary Study Taskforce) in the Bear River Estuary, Willapa National Wildlife Refuge, southwestern Washington...

Figure 2. Locations of benthic and terrestrial (circles), and neuston (solid lines) invertebrate sampling done at the same sites as Columbia River Estuary Study Taskforce fish studies for restored (top images) and reference sites (bottom images), Willapa National Wildlife Refuge, southwestern Washington

Figure 3. Mean monthly temperature estimates (in degrees Celsius $\left[{ }^{\circ} \mathrm{C}\right]$ ) from Odyssey ${ }^{\circledR}$ loggers (bars) and YSI spot measurements (circles), Bear River Estuary, Willapa National Wildlife Refuge, southwestern Washington, March-July of 2014 and 2015

Figure 4. Mean monthly salinity estimates (in Practical Salinity Units [PSU]) from Odyssey ${ }^{\circledR}$ loggers (bars) and YSI spot measurements (circles), Bear River Estuary, Willapa National Wildlife Refuge, southwestern Washington, March-July of 2014 and 2015

Figure 5. Plant stem densities (per square meter $\left[\mathrm{m}^{2}\right]$ ) by reference (Ellsworth Creek and Greenhead Slough) and restored (Lewis Stream and Porter Point) sites, Bear River Estuary, Willapa National Wildlife Refuge, southwestern Washington, March-June of 2014 and 2015.

Figure 6. Monthly benthic invertebrate community density (individuals per square meter [ind/ $\left./ \mathrm{m}^{2}\right]$ ) and composition at restored (Lewis Stream and Porter Point) and reference (Ellsworth Creek and Greenhead Slough) sites, Bear River Estuary, Willapa National Wildlife Refuge, southwestern Washington, March-June of 2014 and 2015.

Figure 7. Monthly terrestrial invertebrate community density (individuals per square meter [ind $\left./ \mathrm{m}^{2}\right]$ ) and composition at restored (Lewis Stream and Porter Point) and reference (Ellsworth Creek and Greenhead Slough) sites, Bear River Estuary, Willapa National Wildlife Refuge, southwestern Washington, March-June of 2014 and 2015

Figure 8. Monthly planktonic community density (individuals per cubic meter $\left[\right.$ ind $\left./ \mathrm{m}^{3}\right]$ ) and composition at restored (Lewis Stream and Porter Point) and reference (Greenhead Slough and Ellsworth Creek) sites, Bear River Estuary, Willapa National Wildlife Refuge, southwestern Washington, March-June of 2014 and 2015

Figure 9. Monthly terrestrial invertebrate drift density (individuals per cubic meter [ind $\left./ \mathrm{m}^{3}\right]$ ) at restored (Lewis Stream and Porter Point) and reference (Greenhead Slough and Ellsworth Creek) sites, Bear River Estuary, Willapa National Wildlife Refuge, southwestern Washington, March-June of 2014 and 2015

Figure 10. Percentage composition of Chinook and coho salmon diets showing most frequently observed prey items, Bear River Estuary, Willapa National Wildlife Refuge, southwestern Washington, March-June of 2014 and 2015.

Figure 11. Mean (top of black bar graphs) and standard error (error bars) Bray-Curtis proportion similarity indexes (PSIs) for salmonids at all four study sites, Bear River Estuary, Willapa National Wildlife Refuge, southwestern Washington, March-June of 2014 and 2015 


\section{Tables}

Table 1. Sampling effort for each invertebrate sample type, Bear River Estuary, Willapa National

Wildlife Refuge, southwestern Washington, March-June of 2014 and 2015

Table 2. Emergent marsh species list, Bear River Estuary, Willapa National Wildlife Refuge, southwestern Washington

\section{Conversion Factors}

U.S. customary units to International System of Units

\begin{tabular}{|c|c|c|}
\hline Multiply & By & To obtain \\
\hline \multicolumn{3}{|c|}{ Area } \\
\hline acre & 0.4047 & hectare (ha) \\
\hline acre & 0.004047 & square kilometer $\left(\mathrm{km}^{2}\right)$ \\
\hline
\end{tabular}

International System of Units to U.S. customary units

\begin{tabular}{|c|c|c|}
\hline Multiply & By & To obtain \\
\hline \multicolumn{3}{|c|}{ Length } \\
\hline millimeter $(\mathrm{mm})$ & 0.03937 & inch (in.) \\
\hline centimeter $(\mathrm{cm})$ & 0.3937 & inch (in.) \\
\hline meter $(\mathrm{m})$ & 3.281 & foot $(\mathrm{ft})$ \\
\hline \multicolumn{3}{|c|}{ Area } \\
\hline square meter $\left(\mathrm{m}^{2}\right)$ & 0.0002471 & acre \\
\hline square meter $\left(\mathrm{m}^{2}\right)$ & 10.76 & square foot $\left(\mathrm{ft}^{2}\right)$ \\
\hline ha (hectare) & 2.471 & acre \\
\hline square hectometer $\left(\mathrm{hm}^{2}\right)$ & 2.471 & acre \\
\hline \multicolumn{3}{|c|}{ Volume } \\
\hline cubic meter $\left(\mathrm{m}^{3}\right)$ & 35.31 & cubic foot $\left(\mathrm{f}^{\mathrm{t} 3}\right)$ \\
\hline \multicolumn{3}{|c|}{ Mass } \\
\hline milligram (mg) & 0.00003527 & ounce, avoirdupois (oz) \\
\hline $\operatorname{gram}(\mathrm{g})$ & 0.03527 & ounce, avoirdupois (oz) \\
\hline
\end{tabular}

Temperature in degrees Celsius $\left({ }^{\circ} \mathrm{C}\right)$ may be converted to degrees Fahrenheit $\left({ }^{\circ} \mathrm{F}\right)$ as follows:

${ }^{\circ} \mathrm{F}=\left(1.8 \times{ }^{\circ} \mathrm{C}\right)+32$.

\section{Supplemental Information}

Note to USGS users: Use of hectare (ha) as an alternative name for square hectometer ( $\left.\mathrm{hm}^{2}\right)$ is restricted to the measurement of small land or water areas.

\section{Abbreviations}

CREST Columbia River Estuary Study Taskforce

PERMANOVA permutational multivariate analysis of variance

PSI percent (proportion) similarity index

PSU Practical Salinity Unit

SFBE San Francisco Bay Estuary Field Station

USGS U.S. Geological Survey

WERC Western Ecological Research Center

WNWR Willapa National Wildlife Refuge 
This page left intentionally blank 


\section{Changes in Aquatic Prey Resources in Response to Estuary Restoration in Willapa Bay, Southwestern Washington}

By Isa Woo, Melanie J. Davis, and Susan E. W. De La Cruz

\section{Executive Summary}

The ongoing restoration of more than 200 hectares of estuarine habitat at Willapa National Wildlife Refuge, southwestern Washington, is expected to benefit a variety of species, including salmonids that use estuarine and tidal marshes as rearing and feeding areas as well as migratory waterbirds. During March-June 2014 and 2015, U.S. Geological Survey Western Ecological Research Center (WERC) initiated a study to assess aquatic prey resources, in coordination with a separate but parallel fish study done by the Columbia River Estuary Study Taskforce. WERC collected data on environmental variables and invertebrate community structure, and the taskforce provided salmonid diet data at restored (Lewis Stream and Porter Point) and reference (Greenhead Slough and Ellsworth Creek) sites. We analyzed these data to determine the functional capacity of the estuary for supporting invertebrate prey resources for fish following restoration.

The results of our analyses were as follows:

- Water temperatures were roughly 0.74 degrees Celsius warmer in 2015 than in 2014 at all sites, with potential consequences for salmonid bioenergetics in June and July.

- Mudflat was colonized by low marsh species such as pickleweed from 2014 to 2015 at restored Lewis Stream. Vegetation community structure remained stable at Greenhead Slough, Ellsworth Creek, and Porter Point in both years, and consisted of halophilic sedges (for example, Carex lyngbyei) and saltgrass (Distichlis spicata).

- Benthic invertebrate community structure consisted of Polychaeta, Nematoda, Oligochaeta, Amphipoda, and Diptera larvae, all of which contribute to the foraging capacity of juvenile salmon and migratory shorebirds. Benthic invertebrate biomass increased as much as 30-fold at some sites from 2014 to 2015.

- Terrestrial invertebrate community structure was dominated by Dipteran flies, especially at restored Lewis Stream, which primarily was unvegetated in 2014. Other key taxa included Hemiptera, Arachnida, and Collembola.

- Aquatic invertebrate prey consisted of planktonic taxa and terrestrial invertebrate drift that fell into the water column from overhanging vegetation. The restored Porter Point had markedly fewer Copepoda, but had the highest levels of neuston biomass primarily due to Dipteran drift (terrestrial flies that fell into the water column). 
- Average proportion similarity index (PSI) values between salmon diet and invertebrate prey availability were relatively low at all sites $(<0.1)$, but were highest at the restored Lewis Stream $(0.105 \pm 0.102)$. This likely was influenced by the predominance of Diptera in the surrounding habitat and in the diets of juvenile Chinook and chum salmon (Oncorhynchus tshawytscha and $O$. keta, respectively).

- The invasive New Zealand mud snail (Potamopyrgus antipodarum) was detected at both Lewis Stream (8 out of 34 aquatic and benthic samples) and Porter Point (1 out of 32 aquatic and benthic samples) restoration sites, but not at reference sites Greenhead Slough or Ellsworth Creek. This invasive species has been observed throughout the Pacific Northwest coastline is not palatable to most fish (including salmonids) and may even be detrimental to some fish species.

- Although invertebrate communities differed between restored and reference sites, invertebrate biomass at the restored Lewis Stream and Porter Point was like or exceeded that of reference sites Greenhead Slough and Ellsworth Creek. The restored sites are still in the early phases of restoration and succession, but our study suggests they have the capacity to support foraging wildlife species such as salmonids.

\section{Background}

Coastal estuaries are critical ecosystems for a variety of wildlife species, serving as important roosting and foraging habitat for migratory birds, and nursery habitat for out-migrating juvenile salmon (Levings and others, 1986; Groot and Margolis, 1991; Erwin and others, 2004). With habitat loss through development and global sea-level rise, the extent of these ecosystems is expected to decrease worldwide (Evans, 1991; Dugan, 1993; Bassett and others, 2013; Sheaves and others, 2015). Willapa Bay in southwestern Washington, has lost an estimated 64 percent of its estuarine wetlands, primarily through diking, channelization, dredging, and filling. As such, optimal habitat for estuarydependent species may be increasingly constrained if mitigation measures are not taken. The Willapa National Wildlife Refuge (WNWR) Comprehensive Conservation Plan (U.S. Fish and Wildlife Service, 2011) specifies that much the Refuge managed pasture habitat will be converted to historical estuarine conditions, including open water, intertidal mudflat, and emergent marsh. The WNWR has implemented a multi-phase plan to remove most of the dike system along the Lewis and Riekkola Units in the Bear River Estuary in southern Willapa Bay and to restore four streams: (1) Lewis Stream, (2) Porter Point, (3) Dohman Creek, and (4) Parker Creek (fig. 1). During Phase I in 2012, 160 acres were restored to tidal processes at the Lewis Tract of the South Bay Unit in the Bear River Estuary. During Phase II in 2014, 140 acres were restored at Porter Point. The restoration at the Riekkola Tract will restore an additional 200 acres of estuarine habitat. These restoration efforts are expected to contribute to the opportunity, capacity, and realized function of Willapa Bay, and to its ability to support estuarine-dependent wildlife.

Evaluating the effect of restoration on the growth and survival of salmon is challenging because their densities are highly variable across space and time (Simenstad and Cordell, 2000; Kondolf and others, 2008), and there is a potential lag time between the development of suitable restored habitat and prey production. Additionally, salmon populations are subject to variable outmigration success and adult return rates, both of which are affected by broad-scale climatic and environmental factors outside the local restoration influence (Greene and others, 2005). Therefore, response to restoration processes may be difficult to detect using fish catch data alone, and as such, fish densities and measurements alone cannot effectively evaluate how fish may take advantage of increased prey abundance and expansion in available restored habitat (Simenstad and Cordell, 2000). 
Given these challenges, Simenstad and Cordell (2000) established a three-tiered framework to assess restoration effectiveness for wildlife (particularly for fish) using Opportunity, Capacity, and Realized Function assessments. Opportunity potential refers to metrics of habitat accessibility and tolerance (that is, appropriate environmental conditions). Capacity refers to the ability of the site to produce prey resources for target species, and Realized Function is a measurable foraging or growth response as a direct result of the restoration accessibility and prey production (Simenstad and Cordell, 2000; Ellings, 2011). In this report, we focus on the invertebrate capacity of the site to produce prey resources for salmonids.

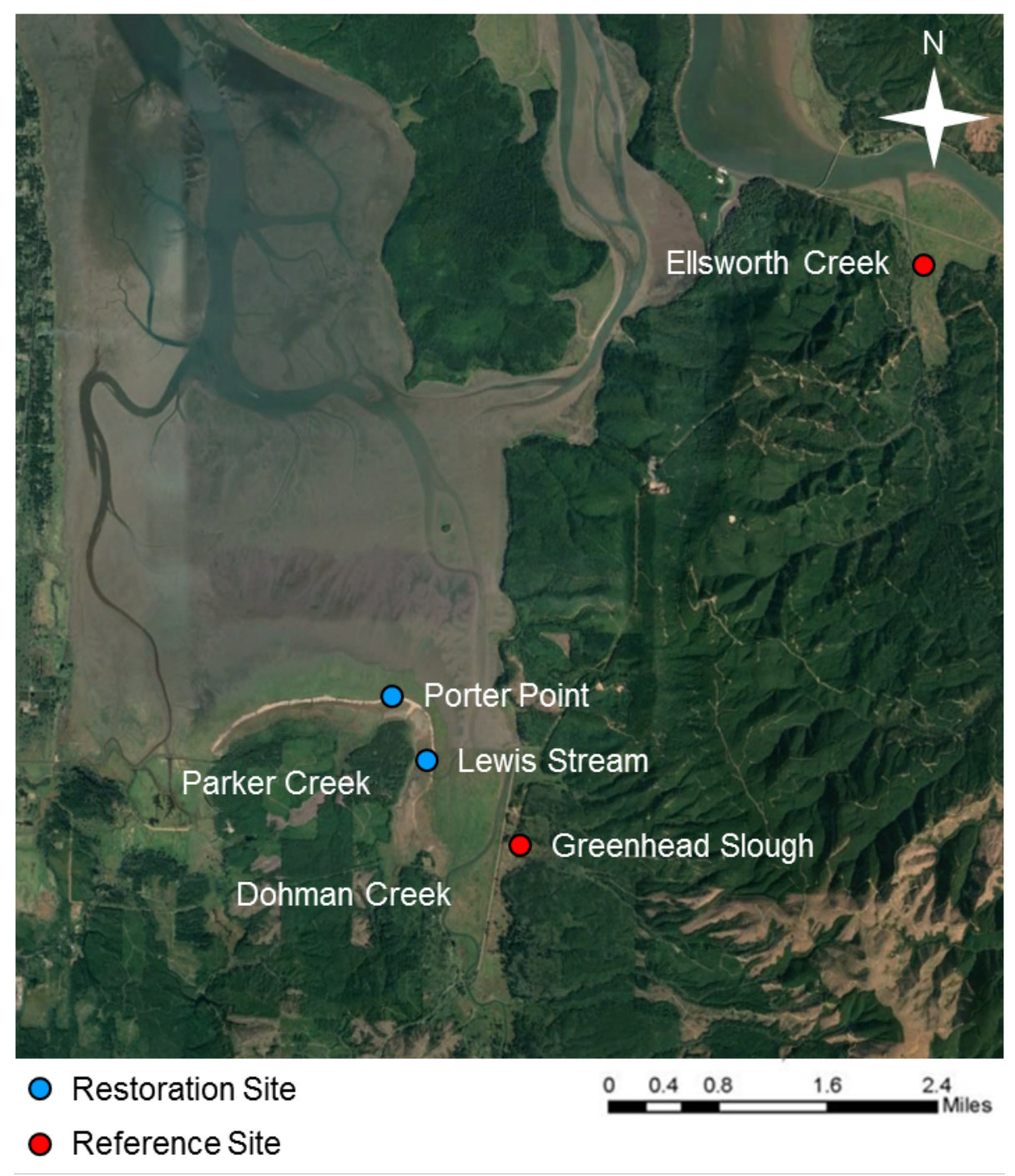

Figure 1. Map of study sites for invertebrates (led by the U.S. Geological Survey Western Ecological Research Center) and salmon (led by the Columbia River Estuary Study Taskforce) in the Bear River Estuary, Willapa National Wildlife Refuge, southwestern Washington. 
The ongoing restoration of more than 500 acres of estuarine habitat at WNWR is expected to benefit a variety of species including overwintering waterbirds, and salmonids that use estuarine and tidal marshes as rearing and feeding areas. The reestablishment of intertidal flat and salt marsh habitat at WNWR presents a unique opportunity to monitor resulting increases in capacity of Willapa Bay for producing invertebrate prey resources for these species. In collaboration with the Columbia River Estuary Study Taskforce (CREST) and U.S. Fish and Wildlife Service, U.S. Geological Survey (USGS) Western Ecological Research Center (WERC) examined prey availability and relationships to biophysical parameters at reference and restored sites in southern Willapa Bay. WERC also collected data on temperature, salinity, vegetation, and invertebrate community structure, and closely coordinated with CREST. CREST fish sampling data on fish species distribution, abundance, size, condition factor, and diet composition were integrated with WERC invertebrate data to summarize the similarity of the diet samples to prey availability to determine the functional capacity of the estuary for supporting wildlife following restoration.

\section{Methods}

In 2014 and 2015, WERC gathered detailed data on invertebrate community structure in conjunction with several environmental variables. Our invertebrate study sites were based on the CREST study and included two restored sites (Lewis Stream and Porter Point), and two reference sites (Greenhead Slough and Ellsworth Creek; fig. 1). During March-June, we collected monthly invertebrate samples at restored and reference sites (table 1) in coordination with fish sampling (led by CREST). This allowed us to discern seasonal and site-specific changes in foraging capacity using basic multivariate analyses.

\section{Environmental Variables}

We collected environmental data to quantify seasonal habitat changes. These variables included continuous water-quality measurements using Odyssey ${ }^{\circledR}$ loggers (Dataflow Systems Ltd., Christchurch, New Zealand), spot readings of channel water quality using a YSI ${ }^{\circledR}$ Professional Plus hand-held multimeter (Yellow Springs Instruments, Yellow Springs, Ohio), soil pore salinity using a refractometer, and $0.25-\mathrm{m}^{2}$ vegetation survey quadrats.

To measure water quality, we installed one Odyssey ${ }^{\circledR}$ data logger at each study site. Loggers were housed in a polyvinyl chloride pipe at the center of the channel, and were suspended by a cable such that the sensor was positioned above the channel floor. We used the National Oceanic and Atmospheric Administration-predicted tidal datum to determine when each data logger was exposed, and omitted temperature and salinity values that were collected when the sensor was not submerged. Additionally, we collected YSI spot measurements during each invertebrate sampling period. Measurements included mean channel temperature (in degrees Celsius), dissolved oxygen (in milligrams per liter), and soil pore salinity (in Practical Salinity Units). We calculated mean and standard deviation temperature and salinity for each site, and used an analysis of variance in R 3.3.0 (R Core Development Team, 2017) to quantify yearly and seasonal trends in water quality.

To evaluate vegetative parameters associated with terrestrial insects, we completed a vegetation survey using a $0.25-\mathrm{m}^{2}$ quadrat placed adjacent to each terrestrial fallout trap (6 per-site). We recorded total cover, maximum height, and stem density for all observed species. We measured soil pore salinity during each vegetation survey by extracting soil moisture through a filter onto a hand-held refractometer. We used survey data to calculate species richness, mean and standard deviation stem density, and mean and standard deviation plant height. We used a permutational multivariate analysis of variance (PERMANOVA) with a Bray-Curtis dissimilarity matrix in $\mathrm{R}$ to determine if vegetative community structure differed between sites and years. 


\section{Invertebrate Prey}

We collected monthly invertebrate samples in coordination with CREST fish sampling at each site (fig. 2) during the 2014-15 outmigration seasons (March-June). Sampling included benthic cores (benthic invertebrates, $n=6$ ), fallout traps (terrestrial invertebrates, $n=6$ ), and neuston tows (aquatic invertebrates, $\mathrm{n}=2$ ) for a total of 14 invertebrate samples per site, per sampling period (table 1). Terrestrial invertebrates that fell into the water and were collected in neuston tows were separated and considered terrestrial invertebrate drift.

We collected benthic cores at low tide using a stainless-steel corer $(2.5 \mathrm{~cm}$ in diameter, $10 \mathrm{~cm}$ deep). We sieved all samples within 1 week of collection using a US No. 35 sieve (0.5-mm mesh). These samples were stored in a jar containing 95-percent ethanol and Rose-Bengal dye solution for later identification. Invertebrate fallout traps measuring $55 \times 38 \mathrm{~cm}$ were installed at each of the four study sites. These traps were used to sample the distribution and abundance of terrestrial invertebrates that fell into the water column. Traps were left in the field for 46-50 hours, after which they were sieved through 0.5-mm mesh and stored in 70-percent ethanol for preservation. Any tipped or overfilled traps were excluded from the analysis. Finally, we sampled aquatic invertebrates using neuston net $(0.4 \times 0.2 \mathrm{~m}, 0.130-\mathrm{mm}$ mesh). The neuston tows were done by boat using 3-minute surface tows and 6-minute sub-surface tows. Samples were preserved in 70-percent ethanol for preservation. A flow meter was attached to the mouth of the net to calculate the total volume of water flowing through each tow.

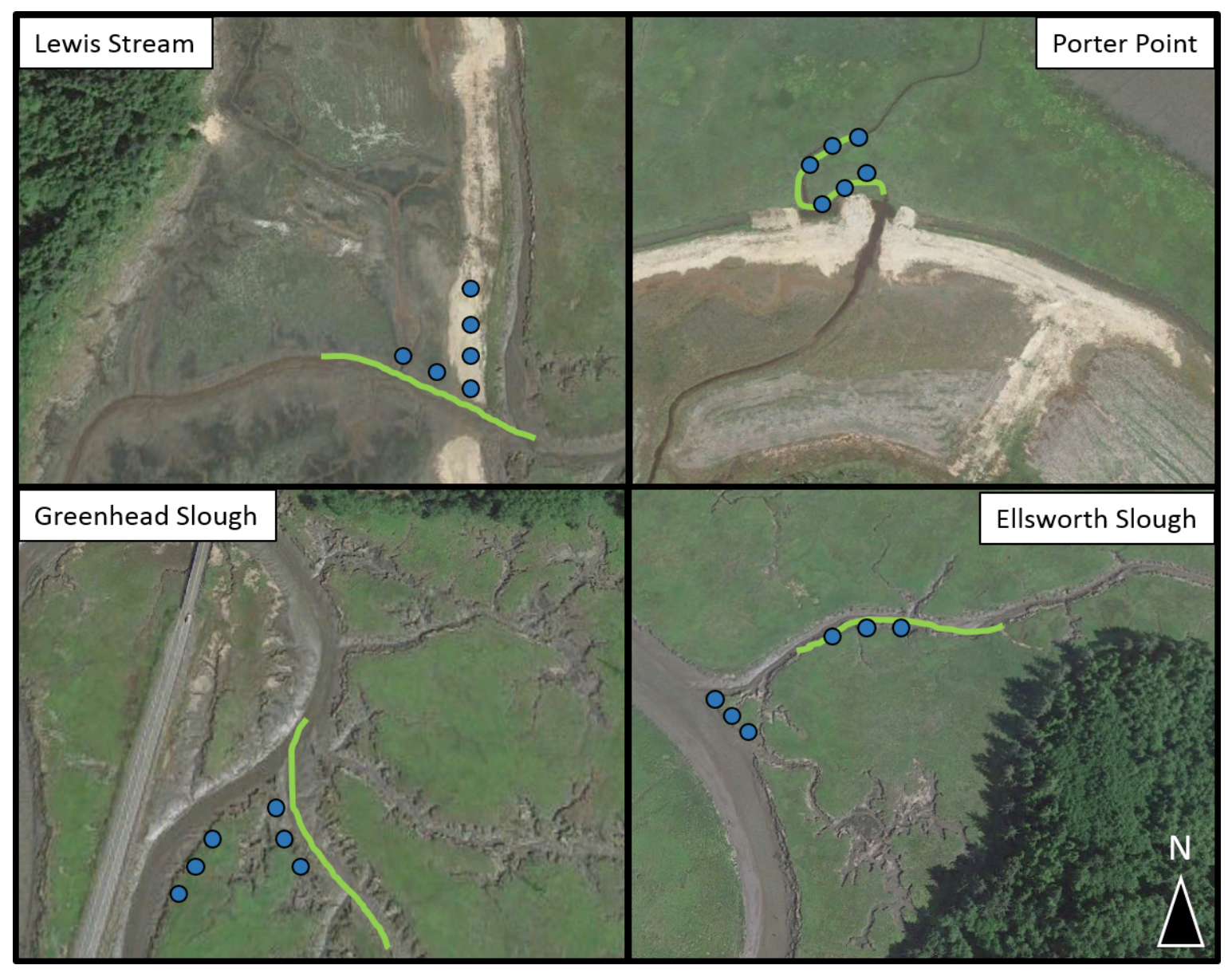

Figure 2. Locations of benthic and terrestrial (circles), and neuston (solid lines) invertebrate sampling for restored Lewis Stream and Porter Point (top images) and reference sites Greenhead Slough and Ellsworth Slough (bottom images), Willapa National Wildlife Refuge, southwestern Washington. 
Table 1. Sampling effort for each invertebrate sample type, Bear River Estuary, Willapa National Wildlife Refuge, southwestern Washington, March-June of 2014 and 2015.

\begin{tabular}{|c|c|c|c|c|c|c|}
\hline \multirow{2}{*}{$\begin{array}{l}\text { Month } \\
\text { sampled }\end{array}$} & \multirow{2}{*}{$\begin{array}{l}\text { Sampling } \\
\text { type }\end{array}$} & \multicolumn{2}{|c|}{ Restored } & \multicolumn{2}{|c|}{ Reference } & \multirow[b]{2}{*}{ Total 2014-15 } \\
\hline & & $\begin{array}{l}\text { Lewis } \\
\text { Stream }\end{array}$ & $\begin{array}{l}\text { Porter } \\
\text { Point }\end{array}$ & $\begin{array}{l}\text { Greenhead } \\
\text { Slough }\end{array}$ & $\begin{array}{c}\text { Ellsworth } \\
\text { Creek }\end{array}$ & \\
\hline \multirow{3}{*}{ March } & Benthic & 6 cores & 6 cores & 6 cores & 6 cores & 48 \\
\hline & Fallout & 6 traps & 6 traps & 6 traps & 6 traps & 48 \\
\hline & Neuston & 2 tows & 2 tows & 2 tows & 2 tows & 16 \\
\hline \multirow{3}{*}{ April } & Benthic & 6 cores & 6 cores & 6 cores & 6 cores & 48 \\
\hline & Fallout & 6 traps & 6 traps & 6 traps & 6 traps & 48 \\
\hline & Neuston & 2 tows & 2 tows & 2 tows & 2 tows & 16 \\
\hline \multirow{3}{*}{ May } & Benthic & 6 cores & 6 cores & 6 cores & 6 cores & 48 \\
\hline & Fallout & 6 traps & 4 traps $^{1}$ & 6 traps & 6 traps & 46 \\
\hline & Neuston & 2 tows & 2 tows & 2 tows & 2 tows & 16 \\
\hline \multirow{3}{*}{ June } & Benthic & 6 cores & 6 cores & 6 cores & 6 cores & 48 \\
\hline & Fallout & 5 traps $^{1}$ & 4 traps $^{1}$ & 6 traps & 6 traps & 45 \\
\hline & Neuston & 2 tows & 2 tows & 2 tows & 2 tows & 16 \\
\hline Season total & All samples & 55 & 54 & 56 & 56 & 443 \\
\hline
\end{tabular}

${ }^{1}$ Three fallout traps at Porter Point and Lewis Stream were destroyed by wildlife in May 2015 and were not replaced.

After processing, we shipped invertebrate samples to the WERC San Francisco Bay Estuary Field Station (SFBE), Invertebrate Ecology Laboratory, for identification and biomass measurement or existing conversion factors. All samples were identified and enumerated to the lowest appropriate taxonomic level in the laboratory following SFBE protocols (modified U.S. Environmental Protection Agency quality assurance-quality control guidelines). We used stereo dissection microscopes at a magnification range of 7-45×. Specialists identified invertebrates at the same taxonomic resolution (family, genus, or species level) as the salmonid diet study (done by CREST) for consistency. Samples were quality-controlled for a sorting efficiency of at least 90 percent.

We converted sample abundances to square-meter density values by dividing the total number of individuals in a sample by the total sample area (or volume, for neuston tows). We used a PERMANOVA with a Bray-Curtis dissimilarity matrix in $\mathrm{R}$ to determine if invertebrate community structure differed between sites and years. Taxa with a frequency of occurrence less than 2.5 percent were excluded from the analysis. We used the SIMPER function from the 'vegan' package in R to quantify species contributions to significant group differences. Invertebrate biomass conversion factors were established from the Nisqually Delta (where the same sampling and processing methods were used; Woo and others, 2017), and because invertebrate taxa were similar, we applied these conversion factors here. 


\section{Salmon Diet}

CREST conducted fish surveys for presence, abundance, size, condition, and diet using a fyke net in March, April, May, and June sampling periods. The net was set on an ebb tide and emptied at variable intervals until the channel was dewatered. Live fish were kept in aerated buckets filled with stream water for processing. Salmonids were measured, weighed, and checked for adipose fin clips or markings. CREST collected dietary information using non-lethal gastric lavage on individuals greater than $60 \mathrm{~mm}$. Complete methods are outlined in a CREST technical document (Columbia River Estuary Study Taskforce, 2015).

CREST identified all macroinvertebrate diet items to the lowest possible taxonomic unit. Each taxonomic group was weighed to derive the average wet weight per sample. We compared invertebrate prey availability in surrounding habitat to these salmonid gut contents using a Bray-Curtis proportion similarity index (PSI) in R. We calculated PSI using the equation:

$$
P S I_{i j}=\frac{2 C_{i j}}{S_{i}+S_{j}}
$$

where $C_{i j} \quad$ represents the sum of the lesser values for species common to fish diet $i$ and site $j$, and

$S \quad$ represents the total number of specimens counted.

Thus, a PSI value of 0 represents no similar taxa in prey communities and diet samples, and a PSI value of 1 represents complete overlap. We compared PSI values between sites, months, and species to assess juvenile salmonid ability to access and benefit from available prey resources throughout the outmigration season.

\section{Results and Discussion}

Our analyses indicated clear trends in invertebrate prey abundance and community structure at restored and reference sites. Differences in prey availability and salmon diet most likely stemmed from ongoing changes in environmental variables such as water temperature, salinity, and vegetative growth.

\section{Environmental Variables}

\section{Water Quality}

An analysis of water temperature at restored and reference sites showed that temperature increased consistently between spring and summer at all sites from about 10 to about $20{ }^{\circ} \mathrm{C}$, but summer temperatures at Porter Point were 12-percent cooler on average than at Lewis Stream, Greenhead Slough, or Ellsworth Creek $\left(\mathrm{F}_{3,1078}=76.13, P<0.001\right.$; fig. 3). Temperatures also were 0.74 ${ }^{\circ} \mathrm{C}$ warmer in 2015 than in 2014 at all sites $\left(\mathrm{F}_{1,1078}=126.82, P<0.001\right)$. YSI spot measurements generally agreed with data from the continuous loggers; however, spot measurements suggested that mean monthly temperatures were as much as $4{ }^{\circ} \mathrm{C}$ higher at Lewis Stream than at the reference sites. This may have been a remnant of collection timing, because benthic samples at Lewis Stream could only be accessed below mean tidal level because of the lower elevation of that site relative to the other sites. 


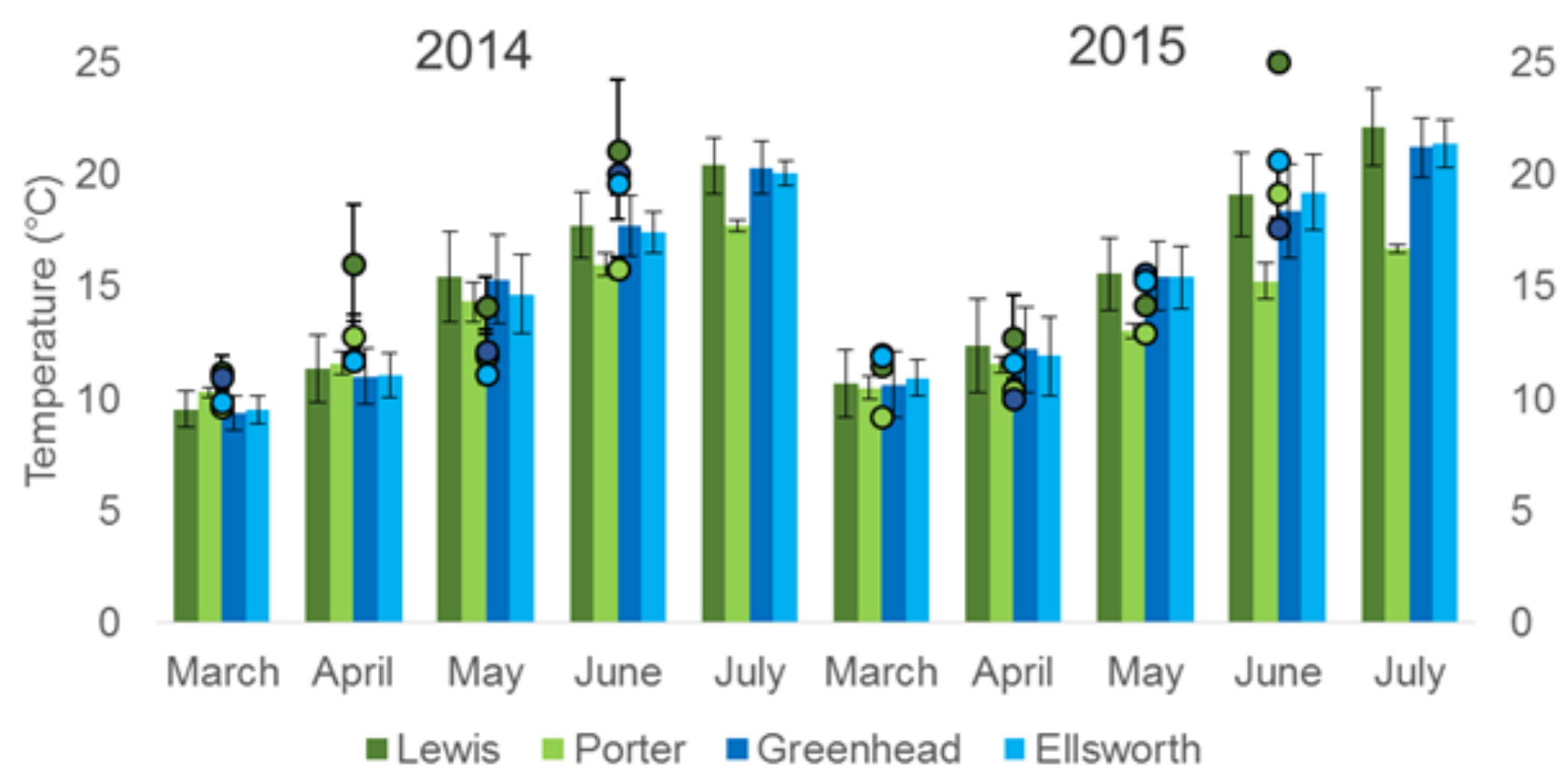

Figure 3. Mean monthly temperature estimates (in degrees Celsius $\left[{ }^{\circ} \mathrm{C}\right]$ ) from Odyssey ${ }^{\circledR}$ loggers (bars) and $\mathrm{YSI}$ spot measurements (circles), Bear River Estuary, Willapa National Wildlife Refuge, southwestern Washington, March-July of 2014 and 2015. Error bars represent plus or minus 1 standard deviation.

The thermal regime of estuarine channels directly influences Pacific salmon growth and consumption. Juvenile salmon experience bioenergetic consequences at temperatures greater than 20 ${ }^{\circ} \mathrm{C}$, and their risk of mortality increases at temperatures greater than $25^{\circ} \mathrm{C}$ (Brett, 1952; Beauchamp and others, 2007). All sites reached summer temperatures greater than $20^{\circ} \mathrm{C}$ in both years. Mean daily water temperatures did not rise higher than $25^{\circ} \mathrm{C}$ on any day at any site; however, YSI spot measurements detected $25^{\circ} \mathrm{C}$ temperatures at Lewis Stream in June, suggesting that environmental conditions in the unvegetated restoration area may have fluctuated outside the optimal range for juvenile salmon. Indeed, higher water temperatures also were observed in restored channels compared to reference channels at the Nisqually Delta, to such an extent as to limit the realized functional benefit of the prey production for juvenile Chinook salmon (David and others, 2014). With adequate sediment supply, we anticipate vegetation to colonize and expand to provide increased benefits of shading for salmonids as the habitat progresses and matures.

Salinity data were not consistently collected in 2014 and 2015 due to intermittent logger failure. Data loggers collected continuous salinity data from March to July 2014 at Lewis Stream, March to July 2014 and February to May 2015 at Porter Point, May to July 2014 at Greenhead Slough, and February to July 2015 at Ellsworth Creek. Additionally, spot measurements for salinity collected via YSI from March to May 2014 were omitted from analysis due to a faulty conductivity sensor. 
Salinity values were lowest at Ellsworth Creek, followed by Lewis Stream (mean \pm standard deviation $[\mathrm{SD}]$-Lewis $=11.58 \pm 1.93$ PSU, Porter $=15.13 \pm 2.09$ PSU, Greenhead $=15.92 \pm 0.34$ PSU, Ellsworth Creek $=10.98 \pm 2.89$ PSU). Salinity increased from March to July at all sites by roughly 30-60 percent $\left(\mathrm{F}_{3,591}=64.09, P<0.001\right.$; fig. 4$)$. YSI spot measurements did not correlate with continuous data. Specifically, spot measurements suggested that Porter Point had lower salinity than the other three sites by 5-15 PSU. These discrepancies may indicate freshwater stratification because data logger measurements were collected from the bottom of the channel, whereas YSI measurements were collected from the top. Increased salinity in the summer months at all sites most likely was the result of decreased freshwater flow after spring flooding subsided.

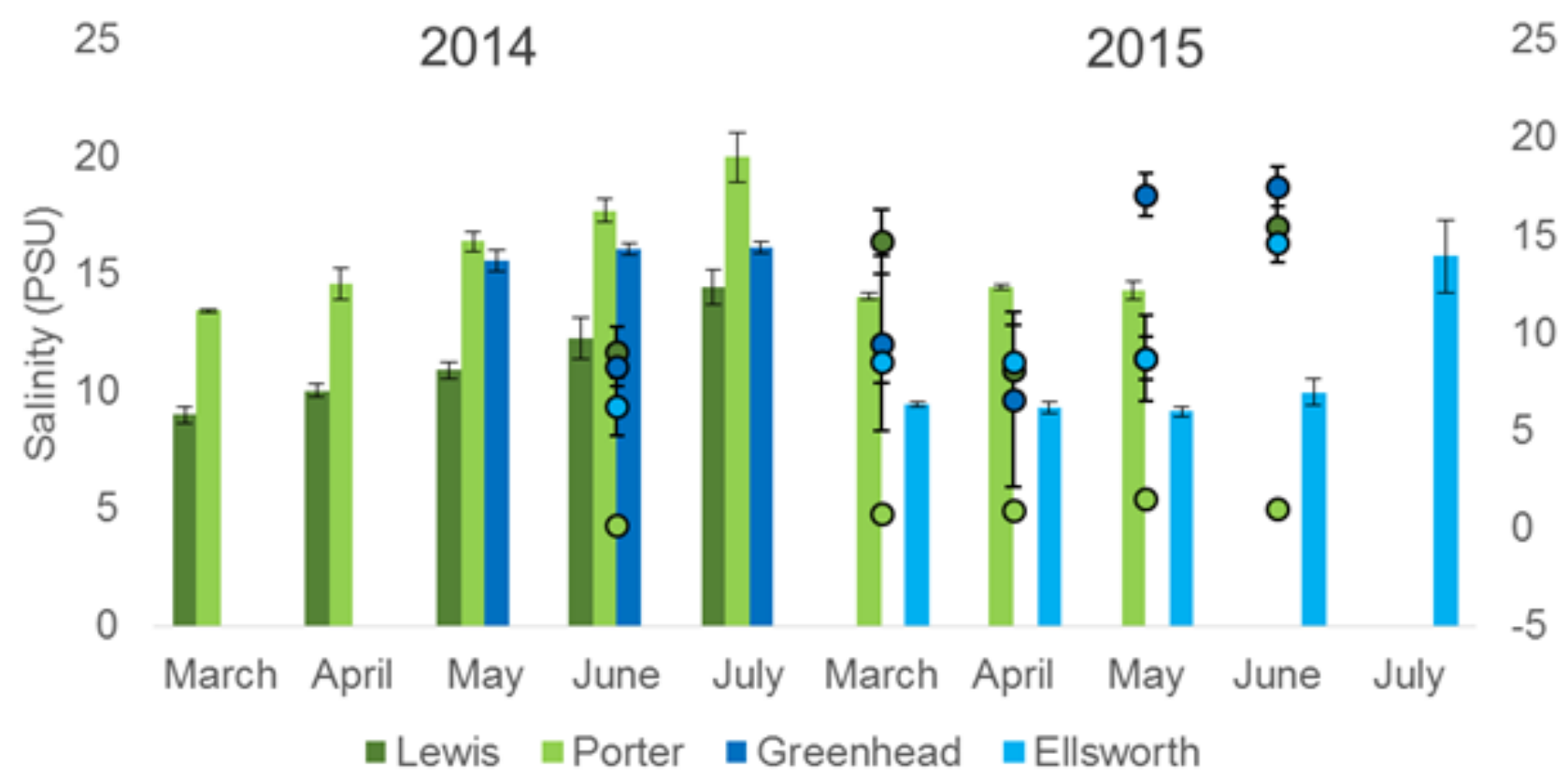

Figure 4. Mean monthly salinity estimates (in Practical Salinity Units [PSU]) from Odyssey ${ }^{\circledR} \log g e r s$ (bars) and YSI spot measurements (circles), Bear River Estuary, Willapa National Wildlife Refuge, southwestern Washington, March-July of 2014 and 2015. Error bars represent plus or minus 1 standard deviation.

\section{Vegetation}

We observed 13 plant species in quadrat surveys across all sites (table 2). Vegetative stem density increased or remained constant over the growing season at Lewis Stream, Porter Point, Greenhead Slough, and Ellsworth Creek, with distinct community differences between restored and reference sites $\left(\mathrm{F}_{3,182}=57.69, P<0.001\right.$; fig. 5). Reference sites generally had greater stem densities than restored sites, especially in 2014, when the Lewis Stream site was still recovering from disturbance $\left(\right.$ mean $\pm \mathrm{SD}$-Lewis $=381 \pm 478$ stems per meter square $\left[/ \mathrm{m}^{2}\right]$, Porter $=736 \pm 388$ stems $/ \mathrm{m}^{2}$, Greenhead $=1,113 \pm 425 \mathrm{stems} / \mathrm{m}^{2}$, Ellsworth $=824 \pm 321 \mathrm{stems} / \mathrm{m}^{2}$ ). Reference sites also had taller vegetation, particularly at Ellsworth Creek, where overhanging sedges reached peak heights by mid-summer (mean $\pm \mathrm{SD}$-Lewis $=0.25 \pm 0.25 \mathrm{~m}$, Porter $=0.52 \pm 0.19 \mathrm{~m}$, Greenhead $=0.42 \pm$ $0.22 \mathrm{~m}$, Ellsworth $=0.81 \pm 1.23 \mathrm{~m}$ ). 
Table 2. Emergent marsh species list, Bear River Estuary, Willapa National Wildlife Refuge, southwestern Washington.

\begin{tabular}{ll}
\hline \multicolumn{1}{c}{ Species } & Common name \\
\hline Agrostis sp. & Bentgrass \\
Deschampsia cespitosa & Hairgrass \\
Hordeum brachyantherum & Meadow barley \\
Vicia villosa & Hairy vetch \\
Carex lyngbyei & Lyngbye's sedge \\
Distichlis spicata & Saltgrass \\
Cotula coronopifolia & Brass buttons \\
Salicornia pacifica & Pickleweed \\
Potentilla anserina & Silverweed \\
Atriplex patula & Spear saltbush \\
Plantago maritima & Salt marsh plantain \\
Glaux maritima & Sea milk wart \\
Triglochin maritima & Seaside arrow grass \\
\hline
\end{tabular}

Reference site vegetation consisted primarily of sedges and grasses such as Lyngbye's sedge (Carex lyngbyei) and saltgrass (Distichlis spicata), respectively. At Greenhead Slough (closest to the Bear River Estuary restoration sites), saltgrass was the dominant species, and mean stem heights of most plants were relatively short $(<0.5 \mathrm{~m})$. In contrast, Ellsworth Creek was dominated by Lyngbye's sedge. By June, most vegetation quadrats at Ellsworth Creek contained thickly growing grasses and sedges that were greater than $1 \mathrm{~m}$ tall.

The restored Lewis Stream site had the most substantial changes post-restoration and had vegetation distinctly different from that of the Porter Point and the reference sites. Several sampling points at Lewis Stream were along a former levee footprint, which also may be more readily colonized by low marsh species such as pickleweed (Salicornia pacifica) and brass buttons (Cotula coronopifolia). Grasses and higher marsh species colonized in 2015. In contrast, the restoration site at Porter Point did not have measurable changes in vegetation post-restoration, despite being downstream of the restoration area and readily accessible for colonizing seeds and plants. However, because this site was at a higher elevation than Lewis Stream, tidal inundation was less frequent. It also was restored 1 year later than the site at Lewis Stream. Plant species at Porter Point were almost identical to those at Greenhead Slough, with generally higher overall stem densities and greater density of bentgrass (Agrostis sp.) in 2015 at Greenhead Slough.

The distinct, low-marsh vegetative community structure observed at Lewis Stream likely was a consequence of higher soil pore salinity values and greater inundation duration than at the other three sampling sites. In 2014, soil pore salinity was 50-70 percent greater at Lewis Stream than at the other three sampling sites (mean $\pm \mathrm{SD}$-Lewis $=11.32 \pm 4.40 \mathrm{PSU}$, Porter $=7.36 \pm 3.04 \mathrm{PSU}$, Greenhead $=$ $6.70 \pm 3.09$ PSU, Ellsworth $=7.40 \pm 1.84$ PSU). Therefore, the site was dominated by halophilic colonizers like pickleweed. 


\section{Ellsworth}

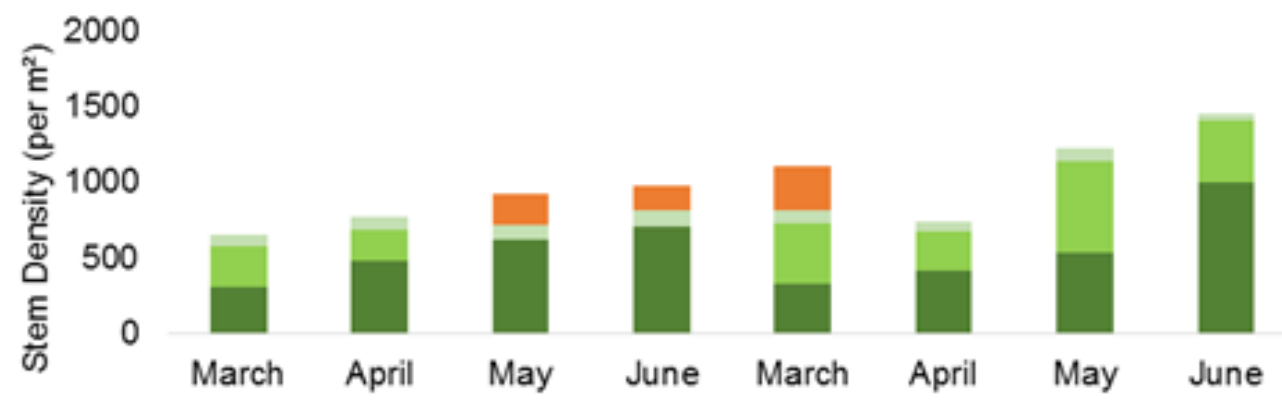

\section{Greenhead}

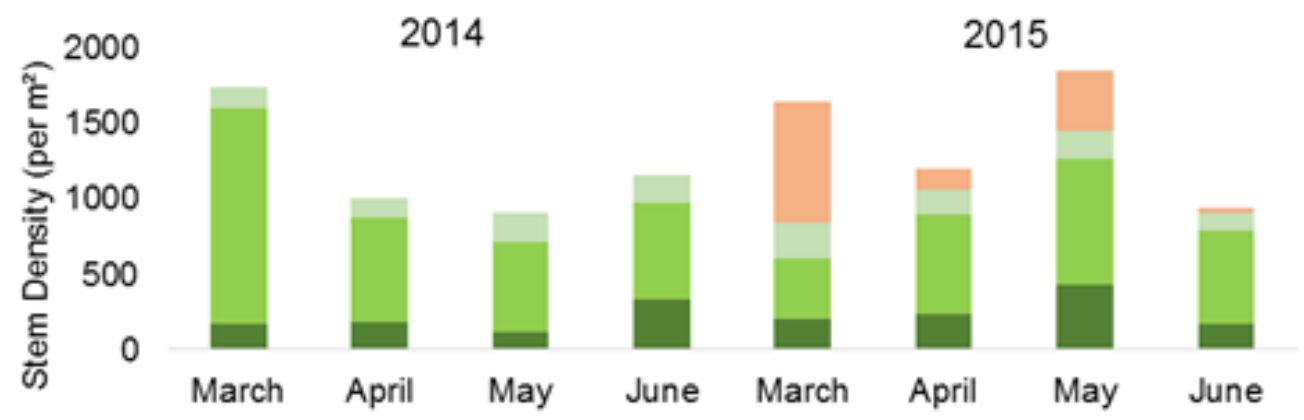

\section{Lewis Stream}
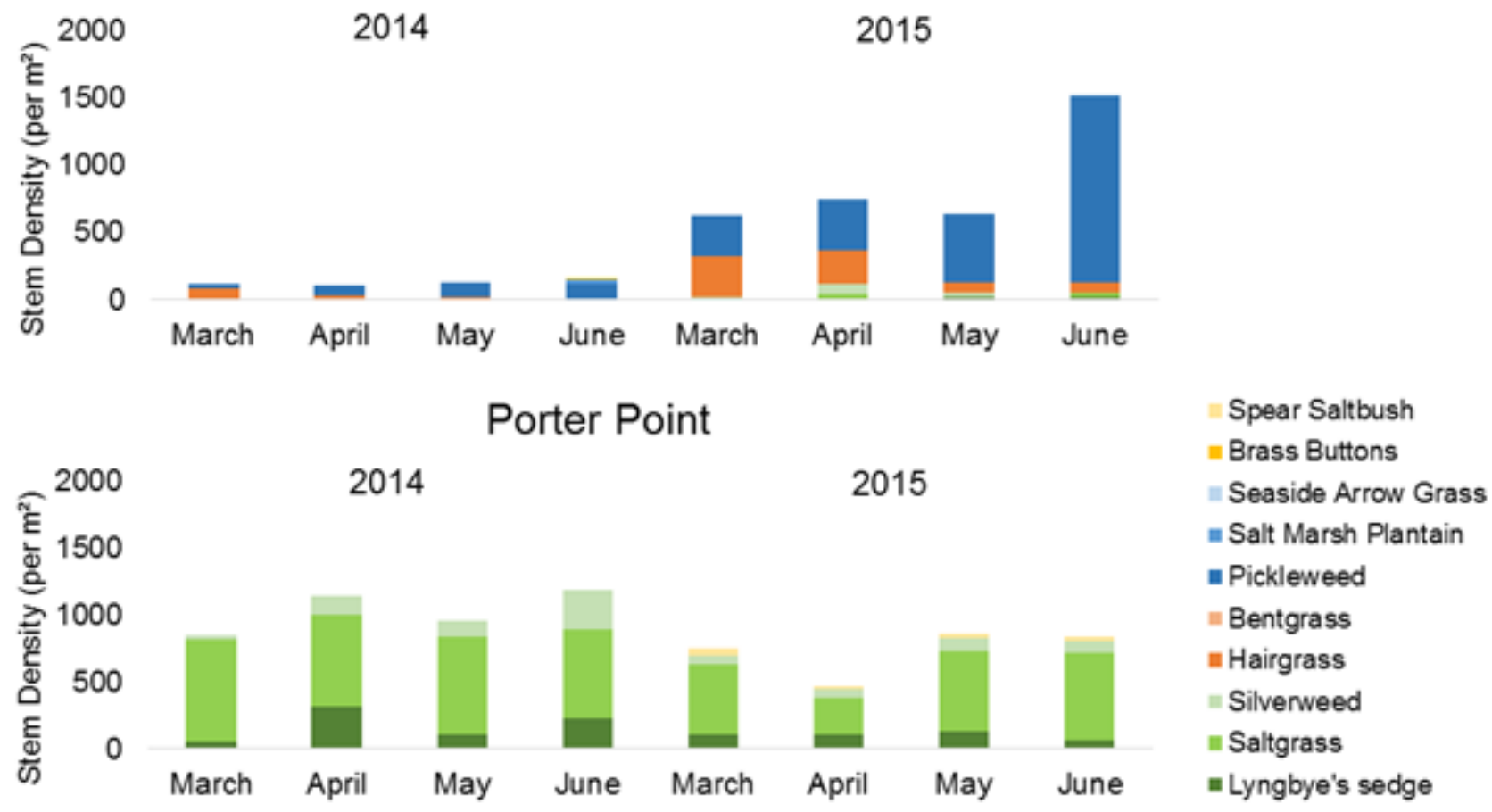

Figure 5. Plant stem densities (per square meter [ $\left.\mathrm{m}^{2}\right]$ ) by reference (Ellsworth Creek and Greenhead Slough) and restored (Lewis Stream and Porter Point) sites, Bear River Estuary, Willapa National Wildlife Refuge, southwestern Washington, March-June of 2014 and 2015. 


\section{Invertebrate Prey}

Benthic

We identified more than 30 invertebrate taxa in Willapa Bay benthic samples, including crustacean species important for juvenile salmonid foraging (appendix 1). We observed site-specific differences in benthic community structure, with all sites having seasonal changes in relative taxonomic abundances $\left(\mathrm{F}_{9,125}=1.40, P=0.029\right.$; fig. 6$)$. Benthic invertebrate community structure in Willapa Bay was characterized by greater abundances of Polychaeta (median $=55$ percent), with Nematoda, Oligochaeta, Amphipoda, and Dipteran larvae also predominating. Total abundances increased markedly from 2014 to 2015 , with as much as 30-fold increases in worms, crustaceans, and Dipteran larvae at all sites $\left(\mathrm{F}_{1,125}=9.63, P<0.001\right)$. This translated to greater overall prey productivity, especially at the restoration sites, where dry weight prey biomass (using established conversion factors from the Nisqually Delta) was sparse in 2014 (mean \pm SD -restored $2014=65.44$ $\pm 56.21 \mathrm{mg} / \mathrm{m}^{2}$, restored $2015=966.67 \pm 1,355.07 \mathrm{mg} / \mathrm{m}^{2}$, reference $2014=871.51 \pm 1,547.94 \mathrm{mg} / \mathrm{m}^{2}$, reference $2015=882.72 \pm 1532.57 \mathrm{mg} / \mathrm{m}^{2}$ ).

Another noteworthy finding was the detection of the invasive New Zealand mud snail (Potamopyrgus antipodarum) at both restoration sites. This species is a voracious invader, which has been observed throughout the Pacific Northwest coastline. The New Zealand mud snail can reach densities of up to 500,000 individuals per square meter $\left(\mathrm{ind} / \mathrm{m}^{2}\right)$ in vegetated and muddy substrate, having major consequences for nutrient fluxes (Davidson and others, 2008). The New Zealand mud snail also is not palatable to most fish species (including salmonids), and can even have detrimental effects on their growth and development (Vinson and Baker, 2008). 


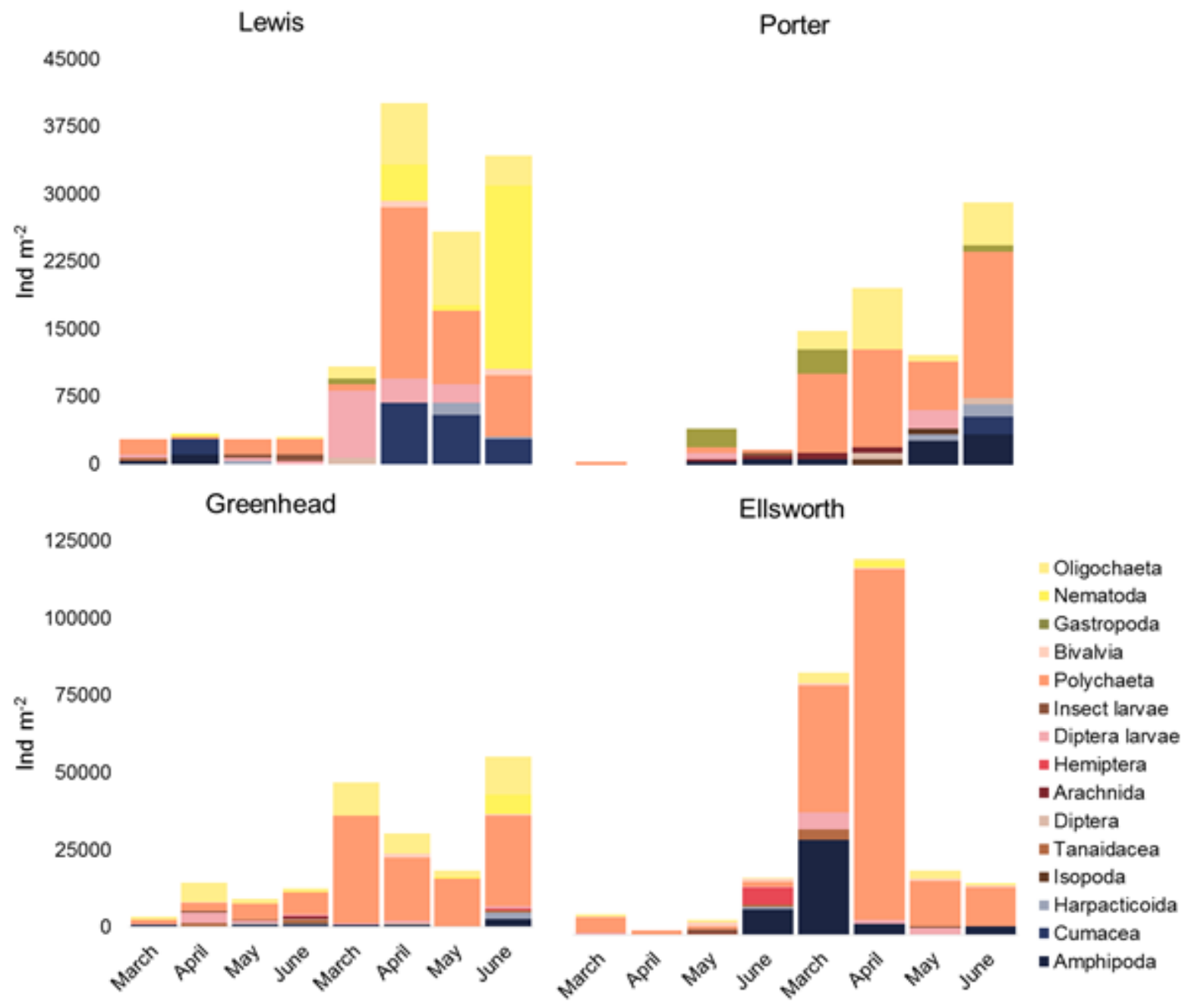

Figure 6. Monthly benthic invertebrate community density (individuals per square meter [ind $\mathrm{m}^{-2}$ ) and composition at restored (Lewis Stream and Porter Point) and reference (Ellsworth Creek and Greenhead Slough) sites, Bear River Estuary, Willapa National Wildlife Refuge, southwestern Washington, March-June of 2014 and 2015. 


\section{Terrestrial}

More than 60 terrestrial invertebrate taxa were captured in fallout traps during the 2014 and 2015 outmigration seasons (appendix 2). Most of these taxa were Diptera, Hemiptera, Collembola, or Arachnida, which provided considerable prey biomass at reference and restored sites (mean $\pm \mathrm{SD}$ Lewis $=153.57 \pm 101.60 \mathrm{mg} / \mathrm{m}^{2}$, Porter $=159.16 \pm 79.07 \mathrm{mg} / \mathrm{m}^{2}$, Greenhead $=229.68 \pm 124.49$ $\mathrm{mg} / \mathrm{m}^{2}$, Ellsworth $=161.64 \pm 94.72 \mathrm{mg} / \mathrm{m}^{2}$ ). The terrestrial invertebrate community at Lewis Stream was markedly different from that of the other sites, containing higher proportions (about 80 percent) of Diptera and Dipteran larvae throughout the year $\left(\mathrm{F}_{9,163}=3.28, P<0.001\right.$; fig. 7$)$. A preponderance of Diptera at marsh restoration sites is not uncommon, as flying detritus-feeders are quicker to colonize disturbed areas than other, non-flying insects (Simenstad and Cordell, 2000; Gray and others, 2002; Tanner and others, 2002; Woo and others, 2018). At the Nisqually Delta, energetically rich Diptera were found primarily in low-lying restoration areas where they tended to congregate on algal mats (Woo and others, 2018). Juvenile salmonids, particularly Chinook salmon, will glean the water surface for drift (Sagar and Glova, 1988; Rondorf and others, 1990; Nielsen, 1992). As such, Diptera that fall into the water column along channel edges can be an energy-rich contribution to salmonid diet along with other terrestrial invertebrate species. 


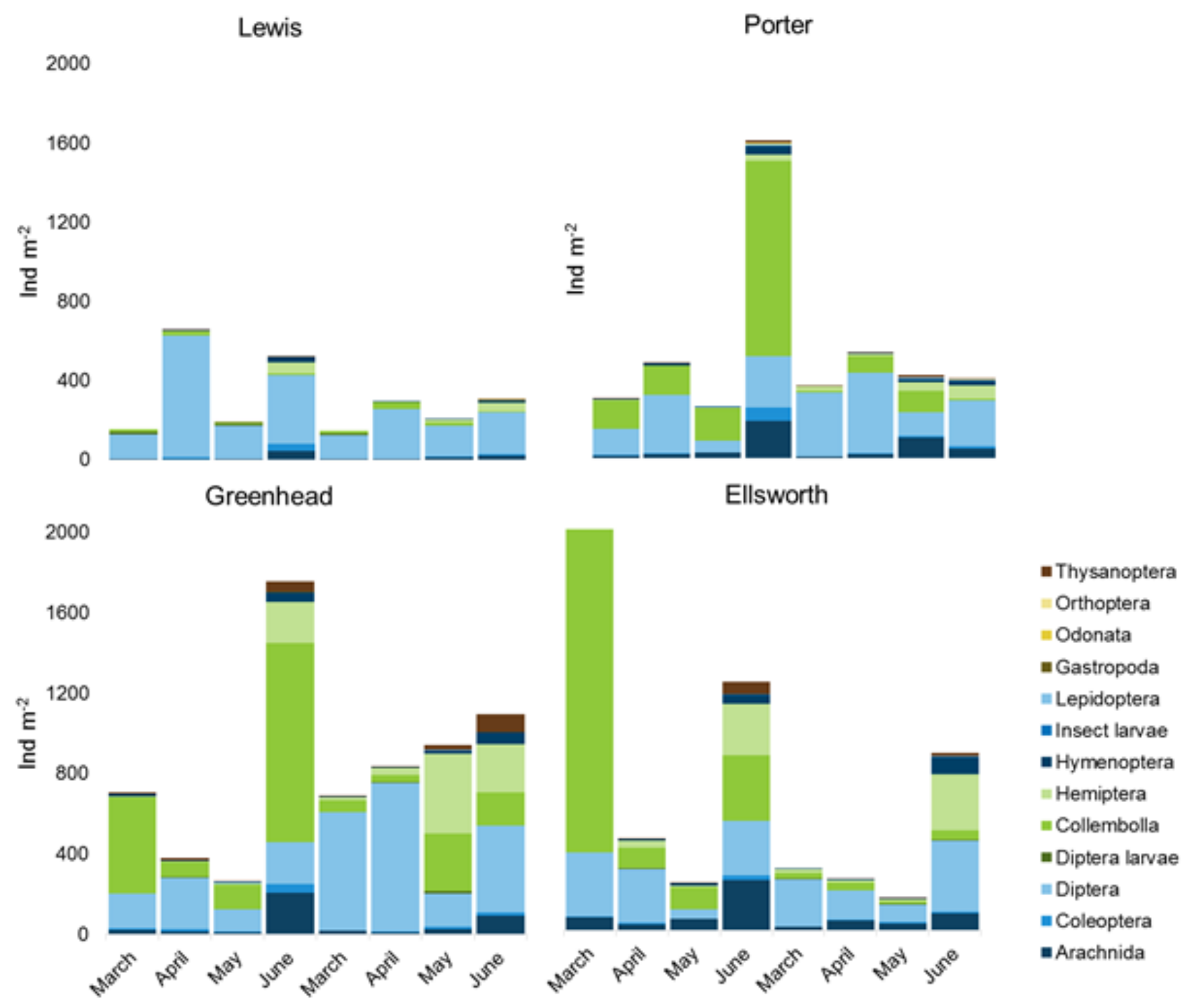

Figure 7. Monthly terrestrial invertebrate community density (individuals per square meter [ind $\mathrm{m}^{-2}$ ) and composition at restored (Lewis Stream and Porter Point) and reference (Ellsworth Creek and Greenhead Slough) sites, Bear River Estuary, Willapa National Wildlife Refuge, southwestern Washington, March-June of 2014 and 2015.

\section{Aquatic}

Aquatic (appendix 3) and terrestrial drift (appendix 4) invertebrates consisted of 96 taxa. Community structure differed by site $\left(\mathrm{F}_{3,31}=2.17, P=0.002\right)$, but did not differ by month or year $(P>$ 0.05). Of the planktonic taxa, Copepoda, Cumacea, Cirripedia nauplii, and Polychaeta were major drivers of community-level differences, with Porter Point having fewer Copepoda, and Greenhead Slough having fewer Cumacea (fig. 8). The drift community was driven by Diptera, with Porter Point having a relatively high proportion of flies falling into the water column (fig. 9). This translated to consistently high aquatic prey biomass estimates at Porter Point, and consistently low estimated biomass at Greenhead Slough (mean $\pm \mathrm{SD}$ - Lewis $=13.89 \pm 12.00 \mathrm{mg} / \mathrm{m}^{3}$, Porter $=24.08 \pm 17.22$ $\mathrm{mg} / \mathrm{m}^{3}$, Greenhead $=6.12 \pm 6.35 \mathrm{mg} / \mathrm{m}^{3}$, Ellsworth $\left.=23.96 \pm 21.69 \mathrm{mg} / \mathrm{m}^{3}\right)$. 
Despite having the greatest abundances, Copepoda contributed very little to prey biomass densities because of their small size $(<0.001 \mathrm{~g}$ dry weight biomass). Instead, it was terrestrial prey that contributed the largest quantities of biomass. Despite having the greatest proportion of Diptera in terrestrial samples, only a few individuals made it into the water column at Lewis Stream. Conversely, Porter Point had the highest proportion of energy-rich Diptera in the water column. This may be because overhanging vegetation acts as a source for terrestrial prey along channel edges (Allan and others, 2003).

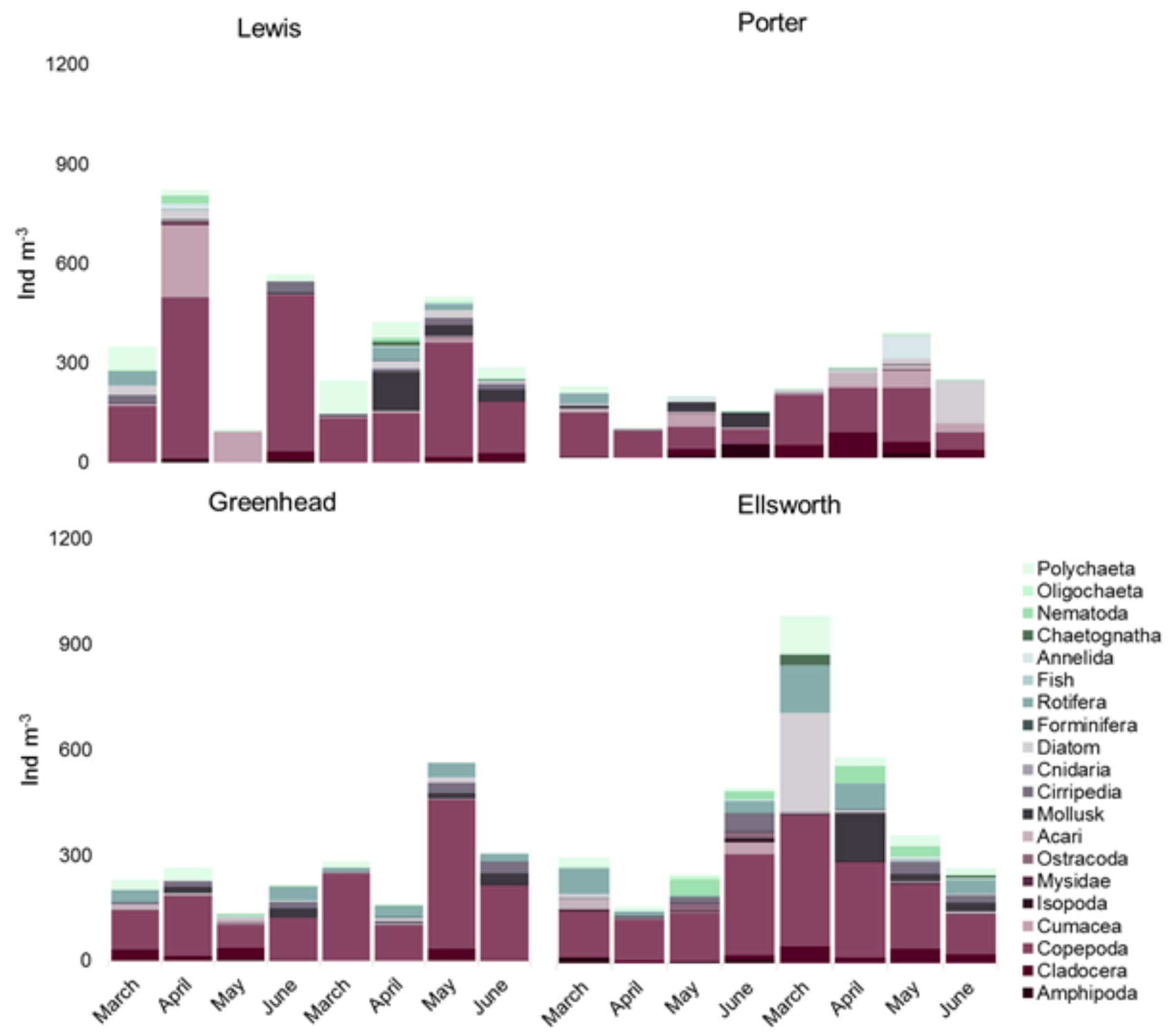

Figure 8. Monthly planktonic community density (individuals per cubic meter [ind $\mathrm{m}^{-3}$ ) and composition at restored (Lewis Stream and Porter Point) and reference (Greenhead Slough and Ellsworth Creek) sites, Bear River Estuary, Willapa National Wildlife Refuge, southwestern Washington, March-June of 2014 and 2015. 
120

90

르 으 60

30

0

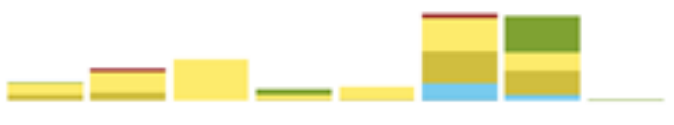

Greenhead

120

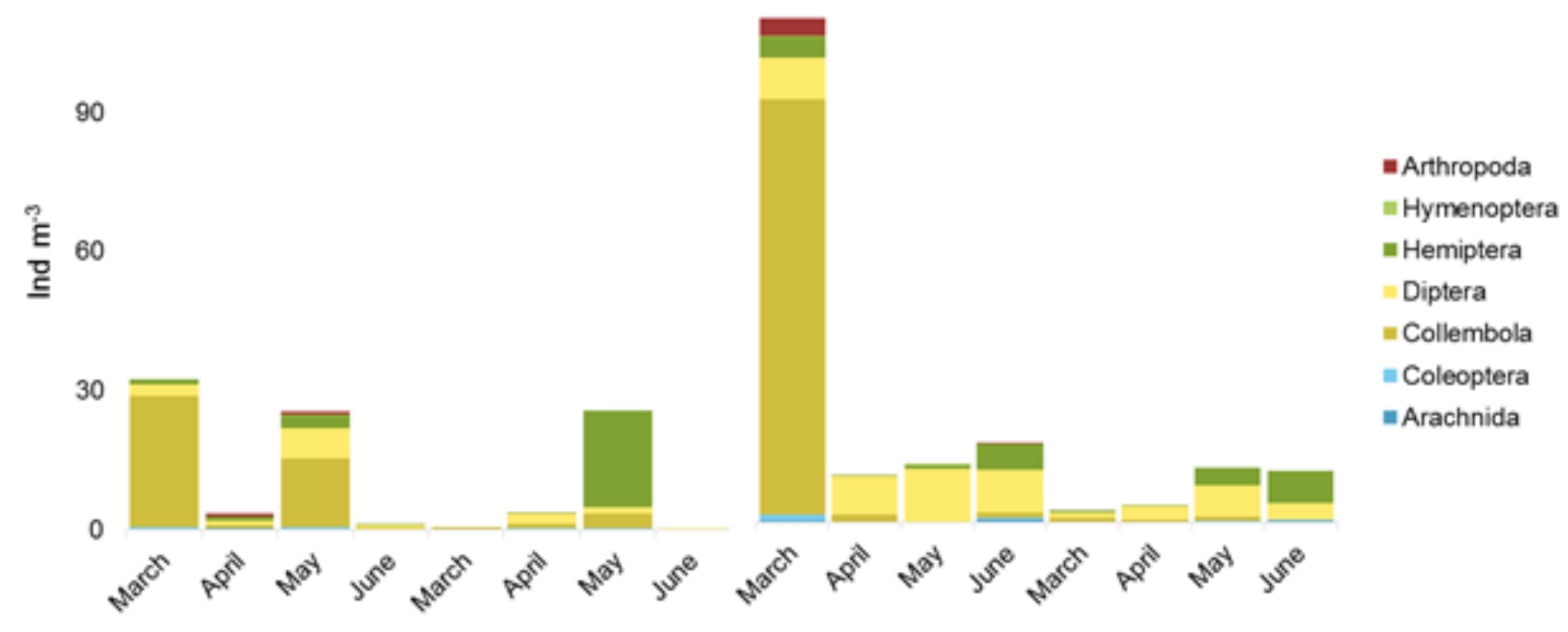

Figure 9. Monthly terrestrial invertebrate drift density (individuals per cubic meter [ind $\left.\mathrm{m}^{-3}\right]$ ) at restored (Lewis Stream and Porter Point) and reference (Greenhead Slough and Ellsworth Creek) sites, Bear River Estuary, Willapa National Wildlife Refuge, southwestern Washington, March-June of 2014 and 2015. 


\section{Salmon Diet}

Complete fish catch and diet data were reported by the Columbia River Estuary Study Taskforce (2015). Chinook and coho salmon consumed aquatic crustaceans such as amphipods, copepods, and cumaceans (fig. 10), and terrestrial invertebrates such as flies (dipterans) and beetles (coleopterans). Bray-Curtis PSI values were low $(<0.25)$ across all months and at all four sites (fig. 11). Although Porter Point had higher terrestrial invertebrate drift values and more streamside vegetation, the highest PSI values $(0.105 \pm 0.102)$ were consistently observed at Lewis Stream. This most likely is due to the high proportion of dipterans at Lewis as compared to the other three sites, and the sizable contribution ( $>50$ percent in most individuals) of dipterans to the resident juvenile salmonid diet. Fish movement between sites can contribute to a lower PSI value, as well as prey selectivity. Further behavior analysis (such as telemetry) would be needed to parse out dietary differences; however, juvenile salmon seem to be accessing and benefitting from available prey in reference and restored habitats. 

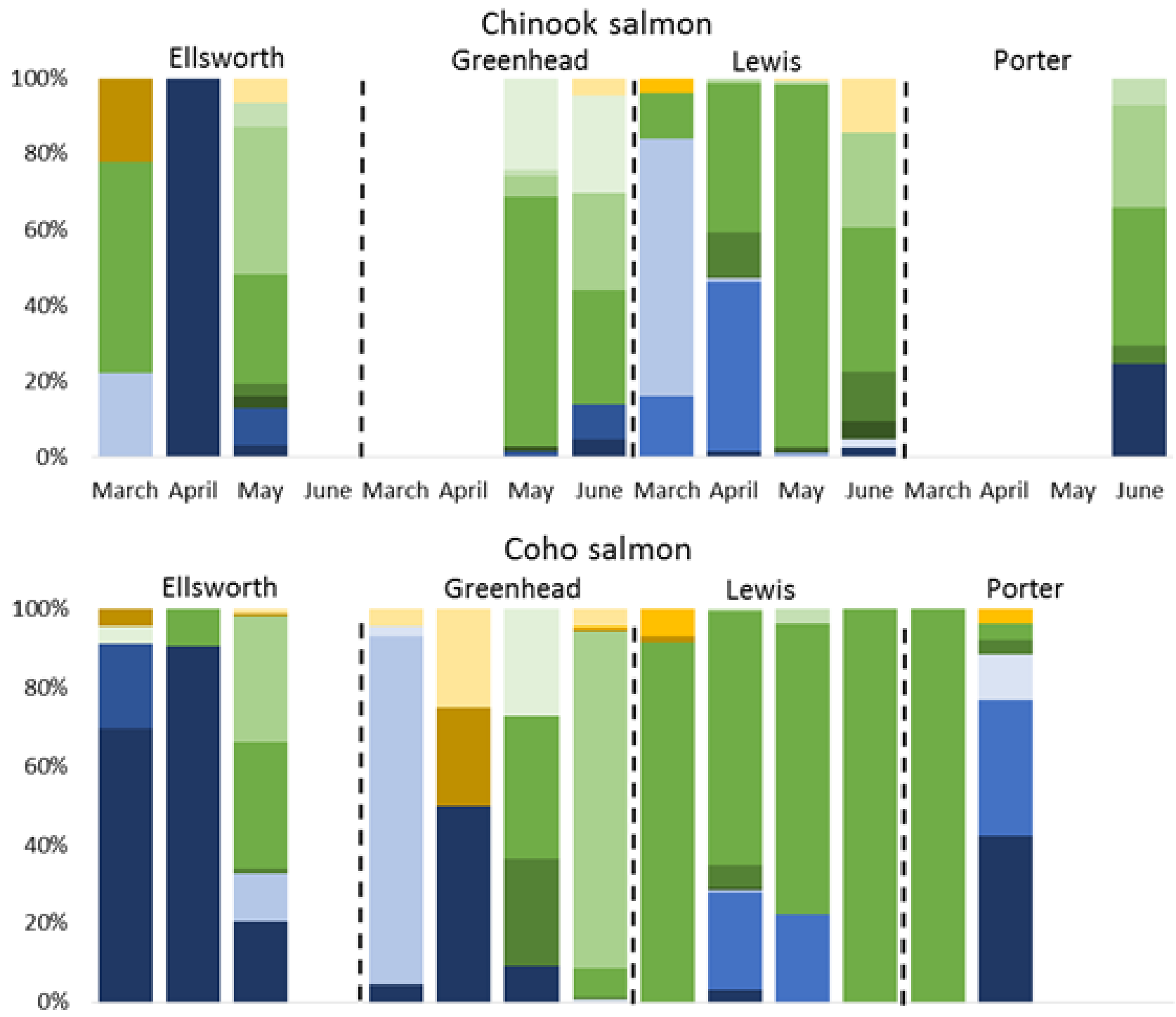

March April May June March April May June March April May June March April May June

\begin{tabular}{|c|c|c|c|c|}
\hline Amphipoda & - Cladocera & = Copepoda & E Cumacea & Mysidae \\
\hline Arachnida & - Coleoptera & = Diptera & a Hemiptera & Hymenoptera Lepidoptera \\
\hline = Acari & n Nematoda & E Polychaeta & Fish & \\
\hline
\end{tabular}

Figure 10. Percentage composition of Chinook and coho salmon diets showing most frequently observed prey items, Bear River Estuary, Willapa National Wildlife Refuge, southwestern Washington, March-June of 2014 and 2015. Diets are shown for Chinook and coho gastric lavage samples obtained by the Columbia River Estuary Study Taskforce. 


\section{2}

\subsection{5}

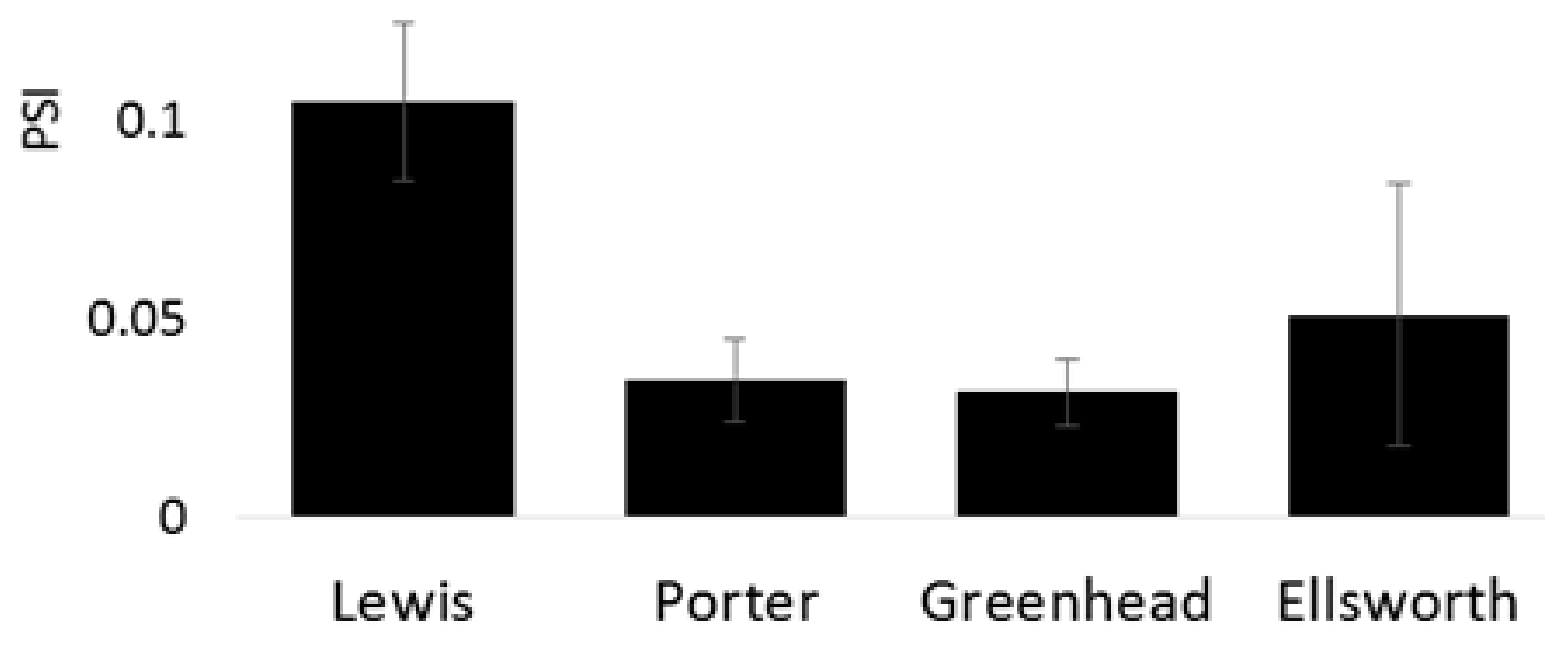

Figure 11. Mean (top of black bar graphs) and standard error (error bars) Bray-Curtis proportion similarity indexes (PSIs) for salmonids at all four study sites, Bear River Estuary, Willapa National Wildlife Refuge, southwestern Washington, March-June of 2014 and 2015.

\section{Conclusion}

Our analysis of hydrology and water quality, vegetation, invertebrate prey, and Chinook (Oncorhynchus tshawytscha) and Coho salmon $($ O. keta) diet data from reference and restoring sites at Willapa National Wildlife Refuge, southwestern Washington, suggests that the restoration areas are producing invertebrate prey resources at biomass densities of benthic, terrestrial, and aquatic prey like densities at reference sites. Juvenile Chinook and coho diets consisted primarily of amphipods, copepods, coleopterans, and dipterans. Amphipods were observed at all four sites, but were found in especially high abundances at Porter Point and Ellsworth Creek. Terrestrial invertebrates that typically are energy-rich prey also were observed at all four sites, but the abundance and biomass of prey captured in fallout traps or as drift were consistently lower at Lewis Stream than at the other three sites. This is most likely related to the scarcity of vegetation on the adjacent marsh plain. Overall proportion similarity index (PSI) values were relatively low $(<0.1)$ for Porter Point, Greenhead Slough, and Ellsworth Creek, which indicates that fish diets were less similar than the prey available to them, and may reflect preference for energy-rich dipterans or general movement (and consumption) in other areas. The PSI value was slightly higher at Lewis Stream $(0.105 \pm 0.102)$ than at the other three sites, signaling that the prey consumed by salmonids was more like prey produced in this habitat compared to the other three sites. As the Lewis Stream site recolonizes with vegetation, invertebrate communities will likely become more similar to reference sites and the higher-elevation Porter Point. Lewis Stream seems to provide invertebrate prey resources for foraging juvenile salmon in its current state. Furthermore, we detected a 30-fold gain in benthic abundances from 2014 to 2015 at Lewis Stream. In 2015, Lewis Stream had the second highest total fish abundance indicating that fish may have been taking advantage of increased invertebrate densities. 
U.S. Geological Survey Western Ecological Research Center invertebrate availability and Columbia River Estuary Study Taskforce datasets were coordinated temporally and spatially to provide complimentary assessments of early phase restorations, compared to reference sites. We determined that the capacity of marshes in the early phases of restoration to produce invertebrate prey is comparable to that of reference sites, with similar findings from the Nisqually River Delta. Data integration, analyses, and synthesis can provide additional insights to the realized function and bioenergetics of potential salmonids using restoring and reference marshes.

We also note the prevalence of benthic polychaetes and amphipods, which also are consumed by shorebirds and waterbirds, indicates that restoration may also increase prey resources for foraging shorebirds as well as estuarine fish. Specific research that incorporates foraging ecology and prey availability would be needed to address restoration benefits for both waterbird and fish populations in Willapa Bay.

\section{Acknowledgments}

This work was supported by U.S. Fish and Wildlife Service Science Support Program, FWINS \# 2516, with logistical support from Willapa National Wildlife Refuge (J. Ferrier and W. Ritchie). Thanks to U.S. Geological Survey (USGS) biologists and technicians L. Belleveau, S. Kaviar, L. Shakeri, S. Blakely, A. Munguia, A. Hissem, and L. Lamere. USGS Invertebrate Ecology Laboratory staff included A. Smith, J. Donald, A. Flanagan, Y. Chan, and C. Norton. Field work was coordinated with the Columbia River Estuary Study Taskforce (J. Smith).

\section{References Cited}

Allan, J.D., Wipfli, M.S., Caouette, J.P., Prussian, A., and Rodgers, J., 2003, Influence of streamside vegetation on inputs of terrestrial invertebrates to salmonid food webs: Canadian Journal of Fisheries and Aquatic Sciences, v. 60, no. 3, p. 309-320, https://doi.org/10.1139/f03-019.

Bassett, A., Barborne, E., Elliott, M., Li, B., Jorgensen, S.E., Lucena-Moya, P., Pardo, I., and Mouillot, D., 2013, A unifying approach to understanding traditional waters-Fundamental properties emerging from ecotone ecosystems: Estuarine, Coastal and Shelf Science, v. 132, p. 5-16.

Beauchamp, D.A., Cross, A.D., Armstrong, J.L., Myers, K.W., Moss, J.H., Boldt, J.L., and Haldorson, L.J., 2007, Bioenergetic responses by Pacific salmon to climate and ecosystem variation: North Pacific Anadromous Fish Commission, v. 4, p. 257-269.

Brett, J.R., 1952, Temperature tolerance in young Pacific salmon, genus Oncorhynchus: Journal of the Fisheries Research Board of Canada, v. 9, no. 6, p. 265-323, https://doi.org/10.1139/f52-016. Columbia River Estuary Study Taskforce, 2015, Bear River Estuary monitoring report: Astoria, Oregon, Columbia River Estuary Study Taskforce, 56 p.

David, A.T., Ellings, C.S., Woo, I., Simenstad, C.A., Takekawa, J.Y., Turner, K.L., Smith, A.L., and Takekawa, J.E., 2014, Foraging and growth potential of juvenile Chinook salmon after tidal restoration of a large river delta: Transactions of the American Fisheries Society, v. 143, no. 6, p. 1515-1529, https://doi.org/10.1080/00028487.2014.945663.

Davidson, T.M., Brenneis, V.E.F., de Rivera, C., Draheim, R., and Gillespie, G.E., 2008, Northern range expansion and coastal occurrences of the New Zealand mud snail Potamopyrgus antipodarum (Gray, 1843) in the northeast Pacific: Aquatic Invasions, v. 3, no. 3, p. 349-353, https://doi.org/10.3391/ai.2008.3.3.12.

Dugan, P., 1993, Wetlands in danger-A world conservation atlas: New York, Oxford University Press, $192 \mathrm{p}$.

Ellings, C.S., 2011, Draft Nisqually National Wildlife Refuge estuary restoration project monitoring framework, unpublished report, Nisqually National Wildlife Refuge, Olympia, Washington. 
Erwin, R.M., Sanders, G.M., and Prosser, D.J., 2004, Changes in lagoonal marsh morphology at selected northeastern Atlantic coast sites of significance to migratory waterbirds: Wetlands, v. 24, no. 4, p. 891-903, https://doi.org/10.1672/0277-5212(2004)024[0891:CILMMA]2.0.CO;2.

Evans, P.R., 1991, Introductory remarks: habitat loss-Effects on shorebird populations, in Proceedings of the XX International Ornithological Congress: Wellington, New Zealand Ornithological Congress Trust Board, p. 2197-2198.

Gray, A., Simenstad, C.A., Bottom, D.L., and Cornwell, T.J., 2002, Contrasting functional performance of juvenile salmon habitat in recovering wetlands of the Salmon River Estuary, Oregon, U.S.A: Restoration Ecology, v. 10, no. 3, p. 514-526, https://doi.org/10.1046/j.1526100X.2002.01039.x.

Greene, C.M., Jensen, D.W., Pess, G.R., Steel, E.A., and Beamer, E., 2005, Effects of environmental conditions during stream, estuary, and ocean residency on Chinook salmon return rates in the Skagit River, Washington: Transactions of the American Fisheries Society, v. 134, no. 6, p. 1562-1581, https://doi.org/10.1577/T05-037.1.

Groot, C., and Margolis, L., eds., 1991, Pacific salmon life histories: Vancouver, British Columbia, Canada, UBC Press, 393 p.

Kondolf, G.M., Williams, J.G., Horner, T.C., and Milan, D., 2008, Assessing physical quality of spawning habitat, in Sear, D., DeVries, P., and Greig, S., eds., Salmon spawning habitat in riversPhysical controls, biological responses, and approaches to remediation: Bethesda, Maryland, American Fisheries Society, 26 p.

Levings, C.D., McAllister, C.D., and Chang, B.D., 1986, Differential use of the Campbell River estuary, British Columbia, by wild and hatchery-reared juvenile Chinook salmon (Oncorhynchus tshawytscha): Canadian Journal of Fisheries and Aquatic Sciences, v. 43, no. 7, p. 1386-1397, https://doi.org/10.1139/f86-172.

Nielsen, J.L., 1992, Microhabitat-specific foraging behavior, diet, and growth of juvenile coho salmon: Transactions of the American Fisheries Society, v. 121, no. 5, p. 617-634, https://doi.org/10.1577/1548-8659(1992)121<0617:MFBDAG>2.3.CO;2.

R Core Development Team, 2017, R-A language and environment for statistical computing: Vienna, Austria, R Foundation for Statistical Computing, https://www.R-project.org.

Rondorf, D.W., Gray, G.A., and Fairley, R.B., 1990, Feeding ecology of subyearling Chinook salmon in riverine and reservoir habitats of the Columbia River: Transactions of the American Fisheries Society, v. 119, no. 1, p. 16-24, https://doi.org/10.1577/15488659(1990)119<0016:FEOSCS > 2.3.CO;2.

Sagar, P.M., and Glova, G.J., 1988, Diel feeding periodicity, daily ration and prey selection of a riverine population of juvenile Chinook salmon, Oncorhynchus tshawytscha (Walbaum): Journal of Fish Biology, v. 33, no. 4, p. 643-653, https://doi.org/10.1111/j.1095-8649.1988.tb05507.x.

Sheaves, M., Baker, R., Nagelkerken, I., and Connolly, R.M., 2015, True value of estuarine and coastal nurseries for fish-Incorporating complexity and dynamics: Estuaries and Coasts, v. 38, no. 2, p. 401-414, https://doi.org/10.1007/s12237-014-9846-x.

Simenstad, C.A., and Cordell, J.R., 2000, Ecological assessment criteria for restoring anadromous salmonid habitat in Pacific Northwest estuaries: Ecological Engineering, v. 15, nos. 3-4, p. 283-302, https://doi.org/10.1016/S0925-8574(00)00082-3.

Tanner, C.D., Cordell, J.R., Rubey, J., and Tear, L.M., 2002, Restoration of freshwater intertidal habitat functions at Spencer Island, Everett, Washington: Restoration Ecology, v. 10, no. 3, p. 564576, https://doi.org/10.1046/j.1526-100X.2002.t01-1-02034.x.

U.S. Fish and Wildlife Service, 2011, Willapa National Wildlife Refuge final comprehensive conservation plan and environmental impact statement: U.S. Fish and Wildlife Service, Willapa National Wildlife Refuge, Ilwaco, Washington, 294 p. 
Vinson, M.R., and Baker, M.A., 2008, Poor growth of rainbow trout fed New Zealand mud snails Potamopyrgus antipodarum: North American Journal of Fisheries Management, v. 28, no. 3, p. 701709, https://doi.org/10.1577/M06-039.1.

Woo, I., Davis, M.J., Ellings, C.E., Nakai, G., Takekawa, J.Y., and De La Cruz, S., 2018, Enhanced invertebrate prey production following estuarine restoration supports foraging for multiple species of juvenile salmonids (Oncorhynchus spp.): Restoration Ecology (online version of record before inclusion in an issue), https://doi.org/10.1111/rec.12658. 


\section{Appendix 1. Total Abundance of (Epi) Benthic Invertebrate Prey Taxa Collected from Samples in Willapa Bay, Washington, 2014-15}

\begin{tabular}{|c|c|c|c|}
\hline Broad ID & Taxonomic group & Taxonomic ID & Total observed \\
\hline \multirow{8}{*}{ Crustaceans } & \multirow{4}{*}{ Amphipoda } & Americorophium sp. & 121 \\
\hline & & Corophiidae & 16 \\
\hline & & Corophium sp. & 6 \\
\hline & & Eogammarus sp. & 33 \\
\hline & Copepoda & Harpacticoida & 22 \\
\hline & Cumacea & Cumacea & 55 \\
\hline & Isopoda & $\begin{array}{l}\text { Gnorimosphaeroma } \\
\text { oregonensis }\end{array}$ & 5 \\
\hline & Tanaidaceae & Sinelobus sp. & 22 \\
\hline \multirow{2}{*}{ Arachnids } & \multirow{2}{*}{ Arachnida } & Acari & 5 \\
\hline & & Unidentified Arachnid & 4 \\
\hline \multirow{16}{*}{ Insects } & \multirow{8}{*}{ Diptera } & Ceratopogonidae adult & 6 \\
\hline & & Ceratopogonidae larvae & 39 \\
\hline & & Chironomidae adult & 3 \\
\hline & & Chironomidae larvae & 26 \\
\hline & & Chironomidae pupae & 4 \\
\hline & & Diptera pupae & 20 \\
\hline & & Dolichopodidae larvae & 7 \\
\hline & & Sciaridae adult & 1 \\
\hline & \multirow{2}{*}{ Coleoptera } & Coleoptera & 2 \\
\hline & & Coleoptera larvae & 2 \\
\hline & Collembola & Collembola & 2 \\
\hline & \multirow{2}{*}{ Hemiptera } & Hemiptera & 4 \\
\hline & & Hemiptera juvenile & 15 \\
\hline & Odonata & Odonata & 1 \\
\hline & Thysanoptera & Thysanoptera & 1 \\
\hline & Insecta & Unidentified Insect & 14 \\
\hline \multirow{3}{*}{ Mollusks } & \multirow{2}{*}{ Bivalvia } & Macoma balthica & 25 \\
\hline & & Mytilus edulis & 2 \\
\hline & Gastropoda & Potamopyrgus antipodarum & 18 \\
\hline
\end{tabular}




\begin{tabular}{|c|c|c|c|}
\hline Broad ID & Taxonomic group & Taxonomic ID & Total observed \\
\hline \multirow{13}{*}{ Worms } & Nematoda & Nematoda & 104 \\
\hline & Oligochaeta & Oligochaeta & 248 \\
\hline & \multirow{11}{*}{ Polychaeta } & Capitellidae & 241 \\
\hline & & Eteone columbiensis & 13 \\
\hline & & Eteone sp. & 4 \\
\hline & & Hobsonia florida & 116 \\
\hline & & Lysidice sp. & 1 \\
\hline & & Manayunkia aestuarina & 644 \\
\hline & & Nereididae & 18 \\
\hline & & Nereis procera & 10 \\
\hline & & Phyllodocidae & 2 \\
\hline & & Streblospio benedicti & 76 \\
\hline & & Unidentified Polychaete & 8 \\
\hline
\end{tabular}




\section{Appendix 2. Total Abundance of Terrestrial Invertebrate Prey Taxa Captured in Fallout Traps from Willapa Bay, Washington, 2014-15}

\begin{tabular}{|c|c|c|}
\hline Broad ID & Taxonomic group & Total observed \\
\hline \multirow{2}{*}{ Arachnida } & Acari & 1,184 \\
\hline & Araneae & 624 \\
\hline \multirow{19}{*}{ Diptera } & Brachycera & 225 \\
\hline & Cecidomyidae & 422 \\
\hline & Ceratopogonidae & 890 \\
\hline & Chironomidae & 6,059 \\
\hline & Culicidae & 1 \\
\hline & Diptera & 12 \\
\hline & Dolichopodidae & 471 \\
\hline & Empididae & 5 \\
\hline & Ephydridae & 325 \\
\hline & Muscidae & 4 \\
\hline & Mycetophilidae & 4 \\
\hline & Nematocera & 13 \\
\hline & Phoridae & 324 \\
\hline & Psychodidae & 766 \\
\hline & Saldidae & 83 \\
\hline & Scatopsidae & 147 \\
\hline & Sciaridae & 168 \\
\hline & Sciomyzidae & 30 \\
\hline & Tipulidae & 158 \\
\hline \multirow{5}{*}{ Diptera larvae } & Ceratopogonidae larvae & 16 \\
\hline & Chironomidae larvae & 22 \\
\hline & Diptera larvae & 7 \\
\hline & Dolichopodidae larvae & 4 \\
\hline & Psychodidae larvae & 12 \\
\hline \multirow{3}{*}{ Insect larvae } & Coleoptera larvae & 12 \\
\hline & Lepidoptera larvae & 1 \\
\hline & Unidentified insect larvae & 8 \\
\hline \multirow{10}{*}{ Coleoptera } & Cantharidae & 8 \\
\hline & Carabidae & 58 \\
\hline & Coccinellidae & 18 \\
\hline & Coleoptera & 257 \\
\hline & Curculionidae & 3 \\
\hline & Elateridae & 9 \\
\hline & Leiodidae & 1 \\
\hline & Malthodes & 1 \\
\hline & Nitidulidae & 1 \\
\hline & Staphylinidae & 25 \\
\hline Entognatha & Collembolla & 8,525 \\
\hline Ephemeroptera & Ephemeroptera & 14 \\
\hline
\end{tabular}




\begin{tabular}{lll}
\hline Broad ID & Taxonomic group & Total observed \\
\hline Broad ID & Taxonomic group & Total observed \\
\hline \multirow{3}{*}{ Hemiptera } & Aphidae & 157 \\
& Cercopidae & 87 \\
& Cicadellidae & 229 \\
& Hemiptera & 1872 \\
& Lygaeidae & 11 \\
& Pentatomidae & 2 \\
\hline Hymenoptera & Formicidae & 5 \\
& Hymenoptera & 500 \\
\hline Lepidoptera & Ichneumonidae & 43 \\
\hline Mollusk & Sphecidae & 3 \\
\hline Neuroptera & Lepidoptera & 28 \\
\hline \multirow{2}{*}{ Odonata } & Gastropoda & 3 \\
\hline Oligochaeta & Neuroptera & 5 \\
\hline Orthoptera & Anisoptera & 1 \\
\hline Psocoptera & Odonata & 1 \\
\hline Thysanoptera & Zygoptera & 6 \\
\hline
\end{tabular}




\section{Appendix 3. Total Abundance of Aquatic Invertebrate Prey Taxa Collected from Willapa Bay, Washington, 2014-15}

\begin{tabular}{|c|c|c|}
\hline Broad ID & Taxonomic group & Total observed \\
\hline \multirow{4}{*}{ Amphipoda } & Americorophium sp. & 9 \\
\hline & Ampithoe sp. & 298 \\
\hline & Corophiidae & 99 \\
\hline & Monocorophium sp. & 17 \\
\hline Annelida & Annelida & 400 \\
\hline \multirow{4}{*}{ Bivalvia } & Bivalvia & 72 \\
\hline & Macoma balthica & 1 \\
\hline & Olea hansineensis & 1 \\
\hline & Potamocorbula amurensis & 1 \\
\hline Chaetognatha & Chaetognatha & 159 \\
\hline Chordata & Oikopleura & 24 \\
\hline Cirripedia & Cirripedia & 2,088 \\
\hline Cladocera & Cladocera & 1,720 \\
\hline \multirow{3}{*}{ Cnidaria } & Cnidaria & 6 \\
\hline & Hydrozoa & 1 \\
\hline & Scyphozoa & 8 \\
\hline Coleoptera & Coleoptera larvae & 1 \\
\hline Collembola & Collembola & 673 \\
\hline \multirow{5}{*}{ Copepoda } & Calanoida & 5,559 \\
\hline & Cyclopoida & 7,907 \\
\hline & Harpacticoida & 572 \\
\hline & Poecilostomatoida & 5,209 \\
\hline & Unidentified Copepoda & 26 \\
\hline Isopoda & Isopoda & 1 \\
\hline Cumacea & Cumacea & 1,574 \\
\hline \multirow{2}{*}{ Decapoda } & Caridea & 1 \\
\hline & Decapoda & 4 \\
\hline Diatoms & Bacillarophyceae & 2,016 \\
\hline \multirow{2}{*}{ Fish } & Actinopterygii & 1 \\
\hline & Osteichthyes & 17 \\
\hline Foraminifera & Foraminifera & 15 \\
\hline \multirow{5}{*}{ Gastropoda } & Gastropoda & 1,519 \\
\hline & Olea hansineensis & 17 \\
\hline & Opisthobranchia & 1 \\
\hline & Opithobrachia & 1 \\
\hline & Potamopyrgus antipodarum & 231 \\
\hline \multirow{2}{*}{ Isopoda } & Gnorimosphaeroma sp. & 98 \\
\hline & Idotea & 1 \\
\hline
\end{tabular}




\begin{tabular}{lll}
\hline Broad ID & Taxonomic group & Total observed \\
\hline \multirow{2}{*}{ Mysida } & Sphaeromatidae & 2 \\
\hline Nematoda & Mysidae & 56 \\
\hline Oligochaeta & Neomysis mercedis & 17 \\
\hline \multirow{2}{*}{ Ostracoda } & Nematoda & 664 \\
\hline & Oligochaeta & 63 \\
\hline & Ostracoda & 3 \\
& Podocopa & 193 \\
\hline Polychaeta & Ampharetidae & 1 \\
& Capitellidae & 92 \\
& Eteone sp. & 25 \\
& Glycinde sp. & 1 \\
& Manayunkia aesturiana & 24 \\
& Nereididae & 20 \\
& Polychaeta & 3,428 \\
& Polynoidae & 1 \\
\hline \multirow{2}{*}{ Rotifera } & Sabellidae & 28 \\
& Spionidae & 4 \\
& Streblspio benedicti & 7 \\
& Syllidae & 1 \\
\hline
\end{tabular}




\section{Appendix 4. Total Abundance of Terrestrial Drift Invertebrate Prey Taxa Collected from Willapa Bay, Washington, 2014-15}

\begin{tabular}{|c|c|c|}
\hline Broad ID & Taxonomic group & Total observed \\
\hline \multirow{2}{*}{ Arachnida } & Acari & 581 \\
\hline & Araneae & 13 \\
\hline \multirow{2}{*}{ Coleoptera } & Staphylinidae & 1 \\
\hline & Unidentified Coleoptera & 39 \\
\hline Collembola & Collembola & 71 \\
\hline \multirow{14}{*}{ Diptera } & Asilidae & 2 \\
\hline & Bombyliidae & 1 \\
\hline & Brachycera & 14 \\
\hline & Cecidomyiidae & 2 \\
\hline & Ceratopogonidae & 43 \\
\hline & Chironomidae & 1,035 \\
\hline & Dixidae & 124 \\
\hline & Dolichopodidae & 5 \\
\hline & Ephydridae & 1 \\
\hline & Nematocera & 17 \\
\hline & Psychodidae & 3 \\
\hline & Scatopsidae & 2 \\
\hline & Sciaridae & 3 \\
\hline & Tipulidae & 2 \\
\hline Ephemeroptera & Ephemeroptera & 28 \\
\hline \multirow{7}{*}{ Hemiptera } & Aphididae & 66 \\
\hline & Cercopoidae & 2 \\
\hline & Cicadellidae & 3 \\
\hline & Corixidae & 7 \\
\hline & Lygaeidae & 1 \\
\hline & Saldidae & 1 \\
\hline & Unidentified Hemiptera & 137 \\
\hline \multirow{2}{*}{ Hymenoptera } & Formicidae & 5 \\
\hline & Unidentified Hymenoptera & 4 \\
\hline Lepidoptera & Lepidoptera & 1 \\
\hline Neuroptera & Neuroptera & 1 \\
\hline Odonata & Odonata & 3 \\
\hline Plecoptera & Plecoptera & 1 \\
\hline Thysanoptera & Thysanoptera & 17 \\
\hline Trichoptera & Trichoptera & 3 \\
\hline
\end{tabular}




\section{Appendix 5. Field Photographs}

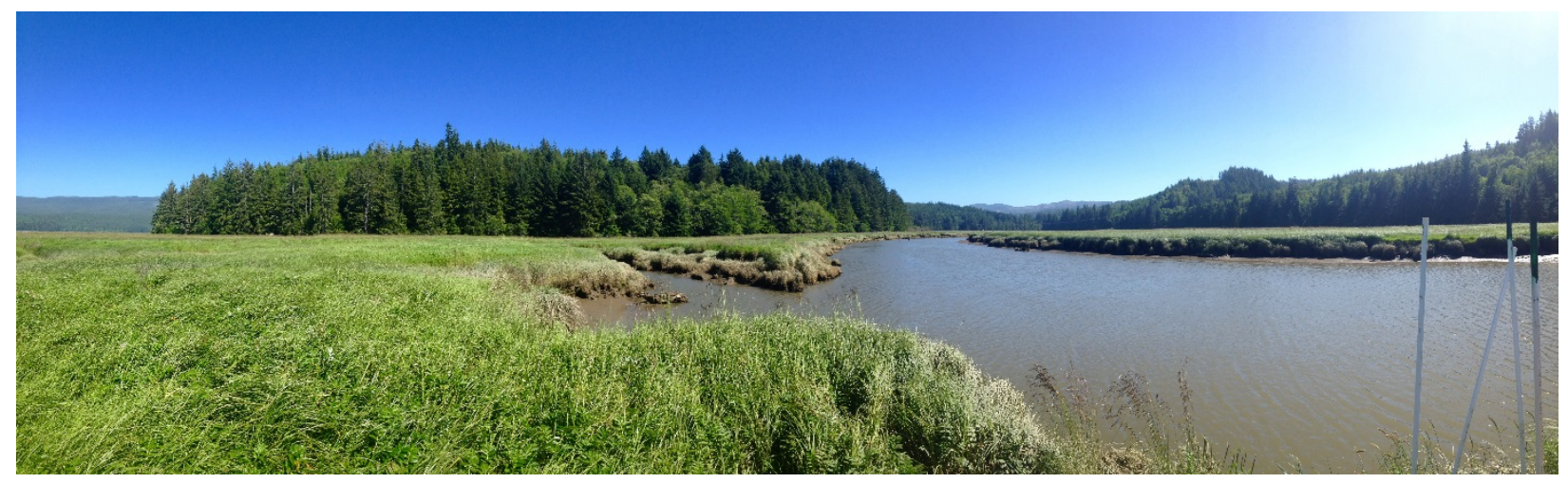

Figure 4-1. Photograph showing panoramic view of Ellsworth Creek, Bear River Estuary, Willapa National Wildlife Refuge, southwestern Washington. The PVC poles in the lower right corner of the photograph represent temporary stakes for terrestrial invertebrate fallout traps. Photograph by S. Blakely, U.S. Geological Survey, June 2015.

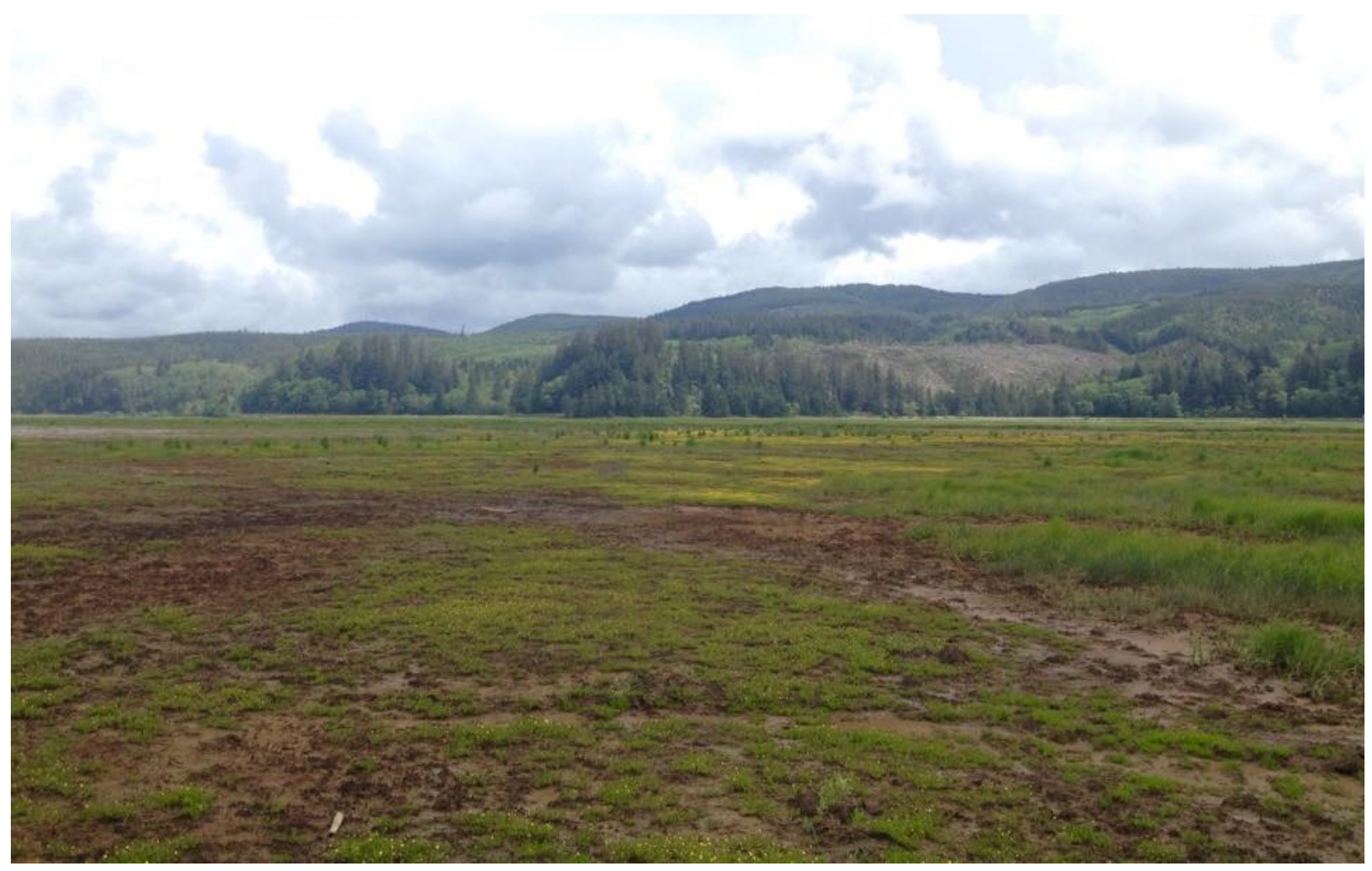

Figure 4-2. Photograph showing Porter Point, Bear River Estuary, Willapa National Wildlife Refuge, southwestern Washington. Photograph by S. Blakely, U.S. Geological Survey, June 2015. 


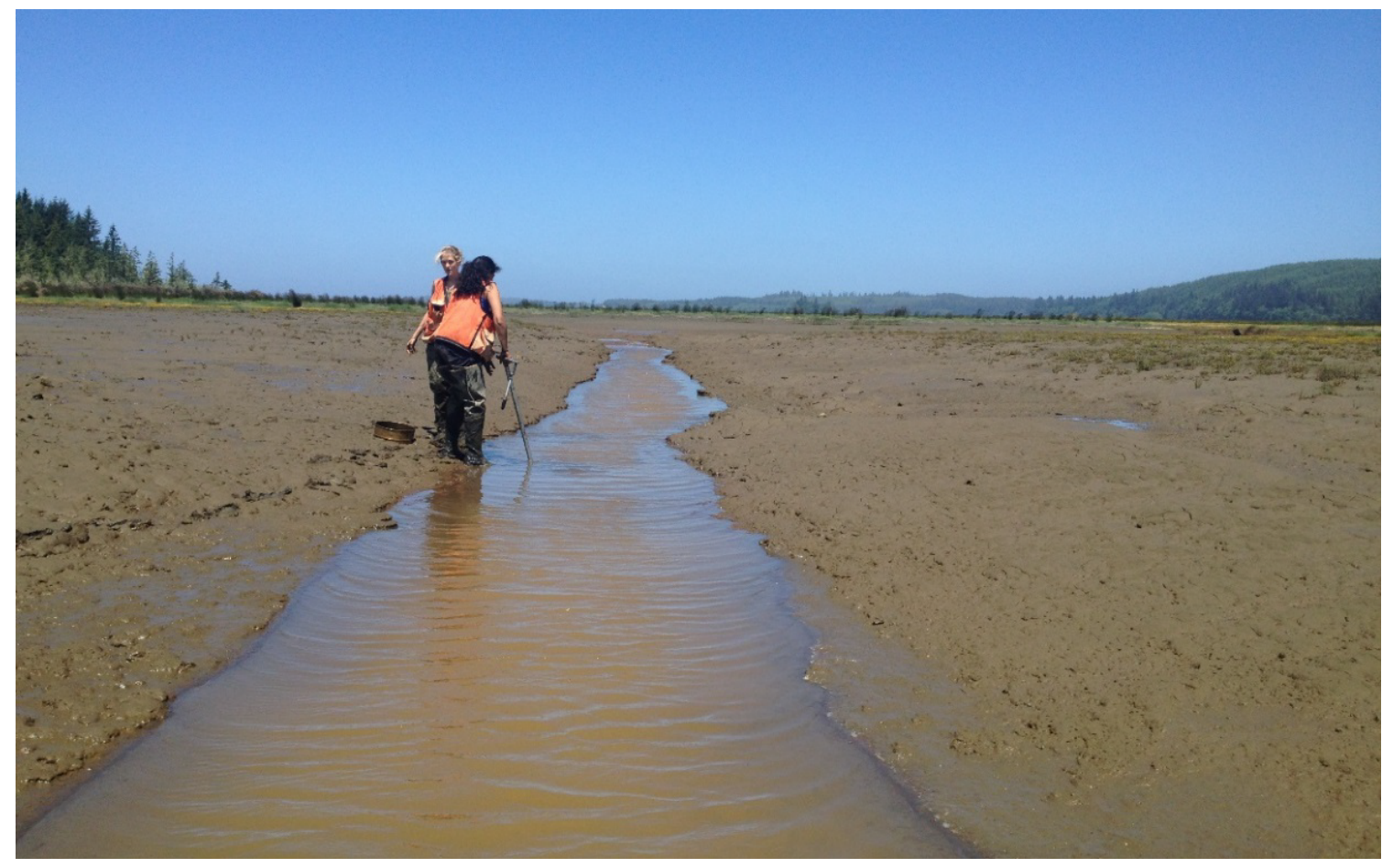

Figure 4-3. Photograph showing sampling of benthic invertebrates at Lewis Stream, Bear River Estuary, Willapa National Wildlife Refuge, southwestern Washington. Photograph by S. Blakely, U.S. Geological Survey, June 2015.

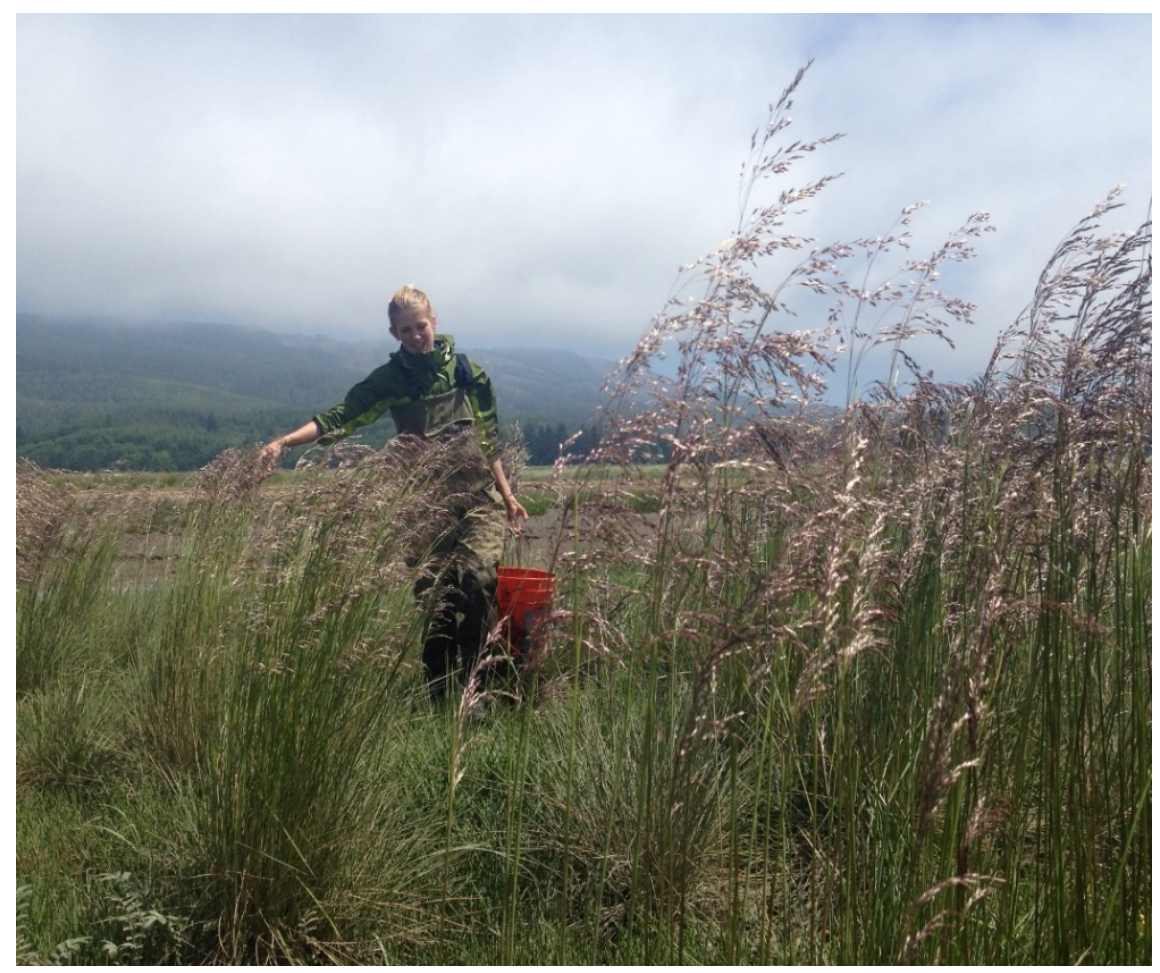

Figure 4-4. Photograph showing fallout trap area at Lewis Stream, Bear River Estuary, Willapa National Wildlife Refuge, southwestern Washington. Photograph by S. Blakely, U.S. Geological Survey, June 2015. 
Publishing support provided by the U.S. Geological Survey

Science Publishing Network, Tacoma Publishing Service Center

For more information concerning the research in this report, contact the Director, Western Ecological Research Center

U.S. Geological Survey

3020 State University Drive East

Sacramento, California 95819

https://www.usgs.gov/centers/werc/ 
